PONTIFÍCIA UNIVERSIDADE CATÓLICA DO RIO DE JANEIRO

\title{
Oportunidades no Mercado Contemporâneo de Distribuição de Música
}

Geovane Ferreira Gomes

Trabalho de Conclusão de Curso

Centro de CIÊnCIAS SOCIAIS - CCS DEPARTAMENTO DE ADMINISTRAÇÃO

Graduação em Administração de Empresas 


\section{Geovane Ferreira Gomes}

\section{Oportunidades no Mercado \\ Contemporâneo de Distribuição de Música}

Trabalho de Conclusão de Curso

Trabalho de Conclusão de Curso, apresentado ao programa de graduação em Administração da PUC-Rio como requisito parcial para a obtenção do titulo de graduação em Administração.

Orientadora: Alessandra Baiocchi A. Corrêa 
"Não há quem não feche os olhos ao cantar a música favorita."

(Fabrício Carpinejar) 


\section{Agradecimentos}

Ao meu amado e poderoso Jeová por ter me dado saúde e força para superar as dificuldades.

Aos meus queridos pais, Dilma e Ricardo, pelo amor, incentivo e apoio incondicional. Assim, como meu irmão Gabriel.

A minha atenciosa orientadora Alessandra Baiocchi, por todo o suporte e carinho. Foi uma grande alegria ter tido a oportunidade de aprender com ela.

$\mathrm{E}$ a todos os professores e amigos que marcaram meus quatro anos na Pontifícia Universidade Católica do Rio de Janeiro. Com certeza foram fundamentais na minha formação. 


\section{Resumo}

GOMES, Geovane Ferreira. BAIOCCHI, Alessandra. Oportunidades no Mercado Contemporâneo de Distribuição de Música. Rio de Janeiro, 2016. Número de páginas p. 76 Trabalho de Conclusão de Curso Departamento de Administração. Pontifícia Universidade Católica do Rio de Janeiro.

Os avanços tecnológicos proporcionaram grandes mudanças na indústria da música. A pirataria, por exemplo, tornou-se uma das grandes ameaças do setor. Porém surgiram também os formatos de distribuição digitais pagos, que atendem consumidores dispostos a pagar por música. Houve também 0 crescimento do público para produtos nostálgicos, como os discos de vinil.

Neste cenário, este estudo investiga as oportunidades promovidas pelos diversos formatos de distribuição de música, focando no comportamento de consumo de dois segmentos geracionais: a Geração X e Y. Para tanto explora conceitos de canais de marketing, envolvimento no consumo, eu estendido, influências no processo de compra, marketing nostálgico e renda discricionária.

Palavras- chave

Indústria da Música, Distribuição de Música, Consumo Geracional, Geração X e Y 


\section{Abstract}

GOMES, Geovane Ferreira. BAIOCCHI, Alessandra. Opportunities In The Contemporary Music Distribution Market. Rio de Janeiro, 2016. Number of pages p. 76 Final Course Work - Administration Departament. Pontifícia Universidade Católica do Rio de Janeiro.

Technological advances have provided major changes in the music industry. Piracy, for example, has become a major threat in the industry. But the paid digital distribution formats indicates that there are still consumers willing to pay for music. In addition to that, the growth in consumption for nostalgic products, such as vinyl discs is a tendency in this market.

Therefore, this study investigates the opportunities promoted by various music distribution formats, focusing in generation behavior for Generation $\mathrm{X}$ and $Y$ according to the following marketing concepts: distribution channels, involvement, extended self, the buying process, nostalgic marketing and discretionary income.

\section{Key-words}

The Music Industry, Music Distribution, Generation Consumption, Generation $X$ and $Y$ 


\section{Sumário}

1 O tema e o problema de estudo 10

1.1. Introdução ao tema e ao problema do estudo 10

1.2. Objetivo do estudo 12

1.3. Objetivos intermediários do estudo 12

$\begin{array}{ll}\text { 1.4. Delimitação e foco do estudo } & 13\end{array}$

1.5. Justificativa e relevância do estudo 13

1.6. Definição dos Termos 13

2 Referencial teórico 15

2.1. Indústria da música 15

2.2. Canais de distribuição de música $\quad 21$

2.2.1. Mídias físicas $\quad 24$

2.2.2. Mídias digitais 26

2.3. Comportamento geracional 27

2.3.1. Geração X 27

2.3.2. Geração $Y \quad 29$

2.4. Envolvimento do consumidor 30

2.5. Eu estendido 31

2.6. Influências no comportamento do consumidor 32

2.7. Marketing nostálgico 33

2.8. Renda discricionária 34

3 Métodos e procedimentos de coleta e de análise de dados do estudo 35

3.1. Etapas de coleta de dados 35

3.2. Fontes de informação selecionadas para coleta de dados 35

3.3. Procedimentos e instrumentos de coleta de dados utilizados 37

3.4. Formas de tratamento e análise dos dados coletados 37

3.5. Limitações do método 38

4 Apresentação e análise dos resultados $\quad 40$ 
4.1. Hábito de consumo 40

4.2. Forma de ouvir 43

4.3. Direitos autorais $\quad 50$

4.3.1. Apenas utilizam mídias pagas $\quad 51$

4.3.2. Apenas utilizam mídias não pagas 52

4.3.3. Utilizam mídias pagas e não pagas 54

4.4. Críticas aos formatos não mencionados 57

4.4.1. CD 57

4.4.2. DVD 58

4.4.3. Blue-Ray 60

4.4.4. Vinil 60

4.4.5. Rádio $\quad 61$

4.4.6. Canais de TV 62

4.4.7. Streaming 63

4.4.8. Downloads grátis (ilegais) 65

4.4.9. Download pago 65

4.4.10. Ringtones 66

$\begin{array}{ll}5 \text { Conclusões e recomendações para novos estudos } & 67\end{array}$

5.1. Sugestões e recomendações para novos estudos 69

6 Referências Bibliográficas $\quad 71$

$\begin{array}{ll}\text { Anexo 1: Roteiro das entrevistas } & 74\end{array}$

$\begin{array}{ll}\text { Anexo 2: Critério ABEP } & 75\end{array}$ 


\section{Índice de Figuras}

Figura 1 - Álbuns das bandas Pink Floyd e Queen....................................... 17

Figura 2 - Canais de marketing de bens de consumo..................................... 22

Figura 3 - Rede de distribuição das mídias físicas.......................................... 25

Figura 4 - Nuvens de palavras: hábito de consumo de música......................... 41

Figura 5 - Nuvem de palavras: formas de ouvir música ................................. 43

Figura 6 - Nuvens de palavras: direitos autorais........................................... 51

Figura 7 - Nuvens de palavras de todas as entrevistas ................................6 69

\section{Índice de Tabelas}

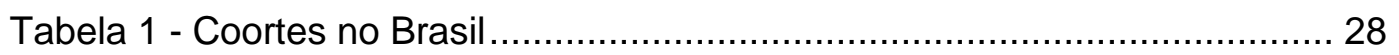

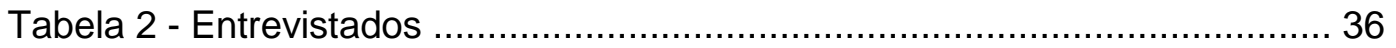

Tabela 3 - Expressões-chave sobre consumo dos entrevistados ..................... 40

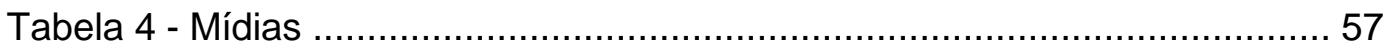




\section{0 tema e o problema de estudo}

Esse capítulo volta-se à apresentação do tema que se pretende desenvolver e do problema de estudo.

Assim, apresenta-se o problema que suscitou a proposta de investigação e respectivos objetivos de pesquisa. Na sequência, são indicadas as suposições, relevância, justificativa e delimitação do estudo.

\subsection{Introdução ao tema e ao problema do estudo}

A internet banda larga e a convergência de aparelhos, como computadores, televisão e smartphones, propiciaram grandes mudanças no mercado da música (MARTINS, 2012). De acordo com a Federação Internacional da Indústria Fonográfica, 95\% das músicas na internet em 2009 eram ilegais ou não pagas (IFPI, 2010), sendo que em 2003 já havia mais de um bilhão de CDs pirateados (ESTADÃO, 2004).

Todavia, apesar do fácil acesso em baixar músicas na internet, há consumidores dispostos a pagar por elas. O iTunes, serviço de música digital paga prova este fato, pois vendeu mais de um bilhão de downloads nos primeiros anos de existência (APPLE, 2005).

Os números do anuário "Mercado Brasileiro de Música 2014", da ABPD (Associação Brasileira de Produtores de Discos) ilustram o aumento do volume de vendas digitais de música. O relatório evidenciou a queda de $15,44 \%$ nas vendas totais de música física (CDs, DVDs e Blu-Rays), de 2013 para 2014. Enquanto que a digital (streaming, telefonia móvel e download de faixas e álbuns) cresceu 30,43\% no mesmo período (ABPD, 2015).

Ainda de acordo com a ABPD, o primeiro semestre de 2015 indicou um novo marco para a música digital - pela primeira vez, o faturamento das músicas digitais das grandes gravadoras brasileiras foi maior que as físicas. Isto se deu pelo crescimento do streaming de música (forma de transmissão instantânea de dados de áudio e vídeo através de redes) que cresceu 53,61\% de 2013 para 2014. Segundo este relatório, o streaming é a tendência na distribuição de música tanto no mercado brasileiro quanto mundial. Já que, "a sinergia entre o mercado de streaming, as operadoras de telefonia móvel e o uso crescente de 
smartphones com acesso à internet, criam condições mais do que favoráveis para que este setor continue crescendo significativamente" (ABPD, 2015, p. 6).

O Comitê de Desenvolvimento da Música Digital, formado por empresas prestadoras de streaming de música (Deezer, Google Play Music, Napster, Rdio e Spotify) solicitou uma pesquisa ao Instituto Opinion Box para entender o impacto da pirataria no serviço de streaming. O estudo revelou que a prática ilegal é $31 \%$ menor para o público que usa o serviço de streaming, ou seja, tal tecnologia parece trazer uma oportunidade para diminuir a ameaça enfrentada pela indústria (Olhar Digital, 2015).

Mesmo assim, há artistas que não veem com bons olhos essa tecnologia, pois os royalties que chegam até eles são muito baixos, devido à mensalidade com conteúdo ilimitado - equivaler ao preço de um CD físico. Por esse motivo, artistas, como a americana Taylor Swift, retiraram todo seu material do Spotify. (ÉPOCA, 2014).

Em uma carta aberta ao The Wall Street Journal, em julho de 2014, a cantora disse que as pessoas ainda compram álbuns físicos quando eles despertam algum afeto. Por esse motivo, a pirataria, o compartilhamento de arquivos e o streaming reduziram as vendas físicas drasticamente (The Wall Street Jornal, 2014). Ressalta-se que ela conseguiu um grande feito com seu último álbum, o 1989, lançado em 2014. Foram vendidos 1,3 milhões de álbuns físicos na primeira semana de lançamento, fato que não ocorria desde 2002 (EONLINE, 2014).

Para se manterem competitivos nesse mercado, artistas precisaram mudar suas estratégias de lançamento. Um dos destaques foi o lançamento surpresa do álbum visual da cantora americana Beyoncé, que inicialmente estava disponível com exclusividade no iTunes, para depois ser lançado em formato físico. Ambas as formas de distribuição foram bem sucedidas. Inclusive, tal acontecimento tornou-se um caso publicado em Harvard: Logo no início do artigo há uma citação da própria cantora. Ela comparou a mudança de hábito do consumidor que, de acordo com as palavras dela, trocou o hábito de apreciar um álbum inteiro para apenas focar nos singles (músicas individuais). Por isso, ela resolveu lançar um álbum surpresa inteiro, incluindo um videoclipe para cada música, na madrugada de 13 de dezembro de 2013 (ELGERSE \& SMITH, 2014).

Essa mudança não se deu apenas no cenário internacional. Artistas brasileiros também se esforçam para que sua obra não seja reduzida a uma música isolada. Para promover o álbum "Nada Pode Me Parar", o cantor 
brasileiro Marcelo D2 criou o "Dia do Clipe", em que, todas as quintas-feiras ele lançou um videoclipe de uma faixa diferente do CD (GAZETA ONLINE, 2014).

Outra tendência são os produtos que estavam em declínio e agora retornam ao mercado, que é o caso dos discos de vinil. Um relatório divulgado pela RIAA (Associação da Indústria de Gravação da América) indicou que a renda gerada com a venda de vinis ultrapassou os serviços de streaming nos Estados Unidos. Enquanto que estes geraram US\$163 milhões no primeiro semestre de 2015, os vinis corresponderam com US\$ 222 milhões (RIAA, 2015).

Diante desta pluralidade nas formas de distribuição - as que tentam sobreviver, as que ressurgiram e as inovadoras - surge o seguinte questionamento: quais são as principais oportunidades do mercado de distribuição de música na atualidade?

\subsection{Objetivo do estudo}

Este trabalho pretende contribuir no entendimento de quais são as principais oportunidades no mercado contemporâneo de distribuição de música.

\subsection{Objetivos intermediários do estudo}

Para se atingir o objetivo final proposto esse estudo prevê, como objetivos intermediários a serem alcançados:

$\checkmark$ Investigar o que o consumidor valoriza - músicas digitais individuais (os singles) ou o álbum completo.

O primeiro objetivo derivou-se do artigo sobre lançamento do álbum surpresa da cantora Beyoncé, onde a cantora disse perceber que o consumo de música estava cada vez mais restrito a músicas individuais. Logo, investigar tal comportamento é de real importância, pois influencia diretamente nos formatos de distribuição de música.

$\checkmark$ Analisar como e onde os consumidores compram música.

O segundo objetivo diz respeito a entender quais os canais preferidos para o consumo de música. Entender o envolvimento dos consumidores de música é fundamental para identificar como e onde eles consomem.

$\checkmark$ Identificar a influência no processo de compra do consumidor. 
Terceiro e último objetivo intermediário busca identificar quais os fatores influenciam o processo de compra dos consumidores, que podem ser influências culturais, sociais ou pessoais.

\subsection{Delimitação e foco do estudo}

Este estudo volta-se mais especificamente para abordar a questão do comportamento do consumidor, nas subculturas etárias $\mathrm{X}$ e $\mathrm{Y}$, frente às formas físicas e digitais de distribuição de música. Tal ângulo de análise se mostra interessante e importante porque a indústria, em questão, sofre constantes mudanças a cada ano.

Além disso, tal estudo será realizado nos primeiros dois bimestres de 2016, com brasileiros.

Embora relevante, não se pretende aprofundar outros itens do composto de marketing (produto, promoção e preço), já que, tal perspectiva poderia tirar o foco do estudo, que são as formas de distribuição.

Além disso, não serão tradadas questões de produções independentes, direitos autorais e rentabilidade.

\subsection{Justificativa e relevância do estudo}

As informações que esse estudo pretende produzir podem se mostrar de interesse para as gravadoras, artistas e prestadores de serviços de música, pois, diante de tantas transformações, faz-se necessário uma revisão nas suas estratégias de distribuição. Afinal, para manter-se competitivo nesse mercado é necessário conhecer as percepções e preferências dos seus consumidores.

Os resultados a serem alcançados também poderão ser úteis para a academia posto que não há muitos trabalhos acadêmicos com foco em distribuição para esta indústria.

\subsection{Definição dos Termos}

Streaming: "Refere-se a músicas em formato digital que são executadas imediatamente sem a necessidade de armazenar os arquivos. A maioria das músicas pode ser ouvida gratuitamente, embora certos conteúdos estejam disponíveis apenas para assinantes" (DESPERTAI, 2011, p. 3).

Single: Termo utilizado pela indústria fonográfica para se referir a uma música que é viável de ser lançada individualmente. Seria a música de trabalho, 
que geralmente ganha um videoclipe. Sendo, muitas vezes, a aposta das gravadoras e artistas para introduzir ou alavancar um álbum, por exemplo. 


\section{Referencial teórico}

Neste capítulo são apresentados e discutidos aspectos conceituais relacionados ao tema que servirão de base para a análise realizada.

\subsection{Indústria da música}

Para falar sobre os meios contemporâneos de distribuição de música, torna-se necessário levantar bibliografias referentes à história dessa indústria, e como o avanço tecnológico a afetou tão profundamente. Por isso, esse capítulo destina-se a trazer, em ordem cronológica, as principais características desse mercado, baseados nos principais aparelhos ou suportes de reprodução musical.

Até aproximadamente 1877, as pessoas não possuíam nenhuma forma de músicas gravadas. Ou seja, consumir música se resumia a ir em concertos ou qualquer outro evento que possibilitasse ouvir ao vivo. Mas, no ano citado, essa realidade mudou: $O$ americano Thomas Edison inventou o fonógrafo - aparelho que gravava sons, inicialmente, em cilindros à base de estanho fixo. Tal aparelho permitiu a reprodução de música, porém, sem a possibilidade de ter uma mídia removível (CROWN, 2009).

Borges (2011) relata que essa invenção teve sua exploração retardada devido à prioridade de Edison com seu outro invento, a lâmpada incandescente, e sua resistência em utilizar o fonógrafo como entretenimento. Ele tinha em mente outras finalidades para a criação deste produto, como criar bonecas falantes, registrar as últimas palavras de pessoas moribundas, ensino de elocução, livros falantes para deficientes visuais, entre outros.

Porém, Charles Tainer e Graham Bell aperfeiçoaram alguns componentes e, em 1886, patentearam o que foi chamado graphophone. Esse novo aparato possuía o cilindro removível, que se tornou o primeiro suporte de som explorado comercialmente. Além disso, diferente do anterior, ele era produzido em papelão com revestimento em cera. Inicialmente era utilizado para ditados comerciais. Esse aparato possuía um botão para voltar a agulha de gravação e um raspador, que tornava o cilindro virgem novamente (BORGES, 2011).

Após a gravação do graphophone, Edison resolveu voltar suas atenções ao fonógrafo. E, para melhorar a fragilidade do cilindro, que rachava devido às 
mudanças de temperatura, ele criou o cilindro em cera maciça. Porém, isso feria a patente de Tainer e Bell que utilizava cera carnaúba e agulha flutuante (BORGES, 2011).

Borges (2011) diz que após a tentativa de um acordo comercial sem sucesso que tentava conciliar os concorrentes com a escolha de um único financiador, ocorreu um processo judicial que criou duas empresas distintas para explorar o cilindro e comercializar seus respectivos produtos - Columbia Phonograph Company General (de Bell e Tainer com o graphophone) e National Phonograph Company (de Edison com o fonógrafo).

Em 1888, o alemão Emile Berliner, que emigrou para os Estados Unidos, desenvolveu e patenteou o gramofone e o disco plano. Inclusive, Edison e Bell já haviam pensado no disco como substituto do cilindro, mas não investiram devido à dificuldade de manutenção da rotação ao chegar no centro do disco (PICCINO, 2008).

As inovações trazidas pelo gramofone foram os discos de sete polegadas e 78 rotações e a possibilidade de duplicação das gravações. Os discos de sete polegadas possuíam apenas um lado com possibilidade de gravar três minutos, em média. Tais discos eram produzidos por uma borracha vulcanizada (ebonite) que era mais resistente do que os cilindros. Em seguida, passou a ser produzido em goma-laca, pois havia dificuldade de prensar a ebonite. Somente na década de 1940 a goma-laca foi substituída pelo vinil, material desenvolvido na década de 1930 (GOMES, 2014).

O gramofone, suportado por discos, instaurou o modelo que iria reger a indústria fonográfica durante o século $X X$. Era um dispositivo "armazenado e preso num suporte que permitia ser transportado e comercializado, possibilitando que a música se transformasse num produto massivo industrial, tornando-se mais um produto produzido e comercializado em larga escala." (BORGES, 2011, p. 31).

Afinal, instaurou-se um novo modelo de consumo. Pois, o gramofone era um instrumento que demandava a compra de discos. Entretanto, apenas vários anos mais tarde houve a possibilidade de os consumidores poderem gravar seus próprios materiais. Além disso, de início, o gramofone favorecia a gravação de vozes, não de instrumentos. Por isso, foram os cantores, principalmente de ópera, que se beneficiaram primeiro desse invento. Contudo, fica evidente que o tal aparato revolucionou a indústria da música (GOMES, 2014).

No final da década de 1940, houve a introdução dos discos de vinil, também conhecidos como Long Play (LPs) no mercado fonográfico. Eles 
possuíam uma maior qualidade sonora e uma capacidade aproximada de vinte minutos em cada lado. Vale lembrar que os discos de 78 rotações possuíam capacidade para apenas três minutos de cada lado (GOMES, 2014).

Em pouco tempo, os LPs tornaram-se sucessos. Afinal, o formato anterior proporcionava apenas duas músicas. Com esse novo formato, surgiu a estética do álbum, "os discos passaram a ser encarados como uma unidade conceitual, e não apenas como uma coleção de canções desconexas" (GOMES, 2014, p. 5). Ou seja, os artistas pensavam na ordenação das músicas, na construção do trabalho. O autor cita alguns exemplos, como Dark Side Of The Moon da banda Pink Floyd e A Night at the Opera, da banda Queen (figura 1).

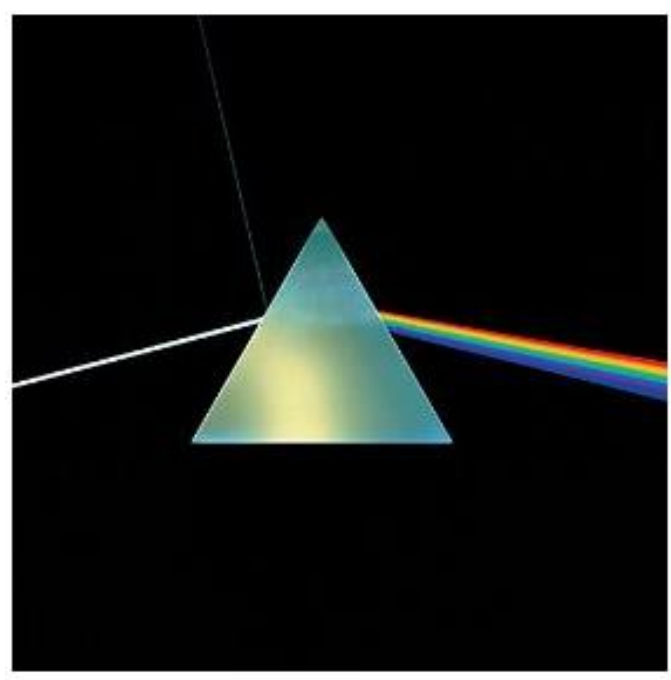

Dark Side Of The Moon (Pink Floyd)

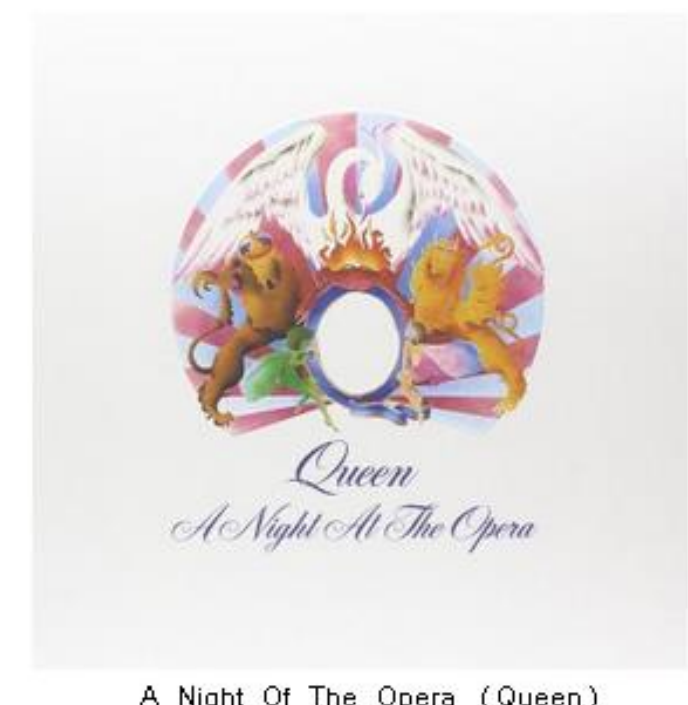

A. Night Of The Opera (Queen)

Fonte: Site Amazon

Figura 1 - Álbuns das bandas Pink Floyd e Queen

$\mathrm{Na}$ década de 1930, os alemães desenvolveram as fitas magnéticas. Porém, só se tornaram conhecidas comercialmente na década de 1970. Antes disso, eram utilizadas apenas para fins profissionais como nas rádios, TVs, produtoras de cinema e gravadoras (CROWL, 2009).

Em 1970 surgiram as fitas K7. A partir dessa década o consumidor possuía duas opções de consumo - o vinil e o K7. O vinil possuía uma durabilidade maior enquanto a fita $K 7$ tinha $o$ preço mais barato, melhor portabilidade e a possibilidade de reprodutibilidade caseira (BORGES, 2011).

Inclusive, o autor Borges (2011) salienta que esses pontos positivos foram um marco na indústria. Afinal, havia a liberdade de ouvir música em aparelhos 
portáteis e até no carro. Além disso, criou-se o consumo individual, porque, ouvir um LP era um motivo de reunião de pessoas, mas o $\mathrm{K} 7$ possibilitava a individualidade no consumo. Outro ponto importante é a possibilidade de fazer cópias tanto de outras fitas como também de LPs e da programação da rádio (BORGES, 2011).

Crown (2009) complementa essa última abordagem ao dizer que as fitas K7 eram uma ótima ferramenta para o conceito de "demos", ou seja, mostrar o trabalho de artistas profissionais ou gravações de qualquer origem. E finaliza seu pensamento por falar do aumento da circulação de gravações independentes e a pirataria de gravações comerciais. Inclusive, Borges (2011) revela que o governo alemão instituiu a cobrança de direitos autorais sobre a produção de aparelhos reprodutores de fitas $\mathrm{K} 7$. Outro ponto que as fitas $\mathrm{K} 7$ revolucionaram foi a criação de uma set-list pessoal. Ou seja, qualquer pessoa podia gravar uma fita com as músicas que quisesse.

Diante desse cenário, a Sony percebeu que as pessoas gostavam de um consumo mais individualista, prático e personalizável. Foi por isso que a empresa criou, em 1979, um aparelho compacto chamado Walkman, que se tornou o "auge da individualização no ato de ouvir música" (BORGES, 2011, p. 47).

Entretanto, o processo de ouvir música sozinho foi gradual. Prova disso foram os primeiros modelos de walkmans desenvolvidos com entrada para dois fones de ouvido, justamente para ouvir junto com outra pessoa. Pouco tempo depois, tornaram-se totalmente individuais (MILLES, 2009).

Em 1982, a Sony lançou o CD, do inglês compact disc (disco compacto). Foi uma grande inovação porque, comparado ao LP e o K7, possuía uma sonoridade sem ruídos e chiados e permitia cerca de setenta minutos de música - com um disco de apenas doze centímetros de diâmetro. No Brasil, porém, começou a ser popular somente em 1990 (BORGES, 2011).

Crowl (2009) comenta que, inicialmente, o público alvo do CD eram os consumidores de música erudita, pois, possuíam ouvidos mais apurados e, com isso, uma necessidade maior de livrar-se dos ruídos e chiados que os LPs e as fitas $\mathrm{K} 7$ proporcionavam.

Assim como as fitas $\mathrm{K} 7$ foram bem aceitas pelos consumidores devido a sua possibilidade de fazer cópias e fitas caseiras, os CDs também foram aceitos rapidamente. Afinal, era fácil de usar e possuía uma qualidade melhor: era necessário apenas o auxílio de um computador e alguns programas. Era tão fácil 
que rapidamente eles eram pirateados e distribuídos com fins lucrativos (CROWN, 2009).

A pirataria chegou em todos os lugares no fim do século XX. Foi a partir deste momento que a indústria fonográfica começa a sentir um desconforto. De acordo com Borges, houve uma maior liberdade para os consumidores: anteriormente eles não possuíam muita escolha - eram forçadas a ouvir o que indústria impunha. Isso começou a mudar com as fitas $\mathrm{K} 7$ e ganhou um impulso maior com os CDs, visto que esses meios possibilitaram a gravação caseira (BORGES, 2011).

Em 1999 surgiu o primeiro programa de compartilhamento massivo de música, o Napster. Ele possuía um funcionamento chamado peer to peer, em português chamado de ponto-a-ponto (popularmente conhecido como P2P), em que os usuários trocavam música sem intermediários e sem custos. Bastava ter internet e o programa instalado no computador. Foi assim, portanto, que surgiu uma grande rede global com milhares de músicas disponíveis. Era tão impressionante que se estima que oito milhões de usuários trocavam vinte milhões de músicas por dia. Todavia, em 2001, a empresa deixou suas operações porque não suportou as ações judiciais vindas das empresas fonográficas e de músicos (BORGES, 2011).

Mas até hoje há formas de se obter música com o mesmo princípio de Shawn Fanning, o jovem programador que criou o Napster. Alguns exemplos de programas que começaram a surgir pouco tempo depois foram o eMule e o Bittorrent. E assim, o termo download (baixar, em português) tornou-se conhecido mundialmente. A partir disso, houve uma 'desmaterialização da música', segundo Borges (2011, p. 55). Porque houve uma separação da música do seu suporte físico.

Um relato pessoal do autor Borges (2011) exemplifica a mudança sem volta na indústria da música. Ele narra que no ano de 1999, quando ele tinha dezoito anos, era muito fã da banda Metallica e ela havia acabado de lançar o álbum S\&M. E como ele morava em Paraty, onde a internet ainda era um artigo de luxo, ele havia encomendado o CD em uma loja de discos. Todos os dias ia até a loja na esperança de que tivesse chegado o álbum $S \& M$. Quando finalmente chegou, passou o dia ouvindo o novo CD. Cerca de dez anos mais tarde, o autor confessa que primeiro lugar onde ele procuraria um novo álbum do Metallica seria na internet. E, provavelmente, conseguiria o álbum antes mesmo de estar disponível nas lojas. Borges foi enfático ao dizer que "a música se 
desmaterializou de tal forma que a geração que cresceu com a internet praticamente não compra mais discos" (BORGES, 2011, p. 56).

O supracitado autor lembra também que assim como a Sony criou o walkman, para comportar as fitas $\mathrm{K} 7$, a empresa também desenvolveu 0 discman para os CDs na década de 1980. Esses aparelhos permitiram a portabilidade da música por meio de uma representatividade da tecnologia vigente da época. De forma parecida, nos dez primeiros anos no século $\mathrm{XXI}$, essa portabilidade foi representada por celulares na venda unitária de músicas, principalmente por meio de venda de ringtones (toques de celular). "Gilberto Gil, o também ex-ministro da cultura revelou que sua música mais vendida naquele momento era um ringtone para celular" (BORGES, 2011, p. 58).

Em 2004, Steve Jobs revolucionou o mundo digital e a indústria da música com o lançamento do iTunes. Nesse site, as pessoas podiam comprar músicas separadas por aproximadamente noventa e nove cents de dólares americanos. No ano seguinte ao lançamento, tornou-se o sétimo maior vendedor de música dos Estados Unidos. Dois anos depois anunciou a venda de um bilhão de músicas, e em 2008, tornou-se o maior vendedor de música do país (KIKKO, 2012).

Genes, Craveiro \& Proença (2012) dissertam sobre o fato que mais ganhou força na internet nos últimos anos - os streamings. Com esse novo modo de ouvir música, os autores perceberam uma mudança no comportamento do consumidor: "Muitas vezes o consumidor não quer adquirir uma versão digital de uma música quando pode ter acesso imediato e grátis a esse conteúdo" (GENES, CRAVEIRO \& PROENÇA, p. 181).

Em 2005, foi lançado o site Youtube, famoso até os dias de hoje, que permite que qualquer pessoa conectada à internet possa assistir a vídeos e ouvir músicas sob demanda, sem fazer download e de forma gratuita. Os autores lembram que não é utilizado apenas para assistir videoclipes, mas também para ouvir áudios. Com isso, muitos artistas lançam, antes de videoclipes, áudios de suas músicas. Além disso, é uma ferramenta em que o consumidor também pode colocar conteúdo. Assim, é possível encontrar uma variedade de músicas, inclusive algumas raras (GENES, CRAVEIRO \& PROENÇA, 2012).

Esse tipo de serviço, quando gratuito, possui receita por meio de adsupported streaming (mantido por propaganda). Ou seja, ao invés de ganhar por música, ganha por meio de espaço destinado a publicidade. Mas, nos dias atuais há streamings com teor premium, em que o usuário paga uma mensalidade para utilizar todo o conteúdo (GENES, CRAVEIRO \& PROENÇA, 2012). 
Genes, Craveiro e Proença (2012) classificam como "interessante" o site Pandora. Ele também é um streaming que disponibiliza as músicas por meio de "estações" com o estilo de música personalizado por meio de um algoritmo chamado Music Genome Project (Projeto Genoma Musical), que sugere músicas nessa playlist personalizada, de acordo com o gosto do cliente. Ao ouvir a música, o consumidor assinala se gostou ou não. Assim, o sistema se aperfeiçoa cada vez mais ao gosto do cliente. Há também informações sobre o artista e música, além de indicar onde comprar tal trabalho em lojas físicas e virtuais.

Porém, o próprio CEO da companhia, Tim Westergren, informou que os gastos com execução são os maiores, o que chega a quase metade dos lucros anuais. Ademais, a empresa não possui uma economia de escala. Pois, quando mais usuários utilizam, mais royalties a Pandora paga, e o lucro não cresce na mesma proporção (GENES, CRAVEIRO \& PROENÇA, 2012).

\subsection{Canais de distribuição de música}

Canais de distribuição são um "conjunto de caminhos que um produto segue depois da produção, culminando na compra ou na utilização pelo usuário final" (KOTLER \& KELLER, 2012, p. 448).

Após entender o conceito de canais de distribuição faz-se necessário abordar o que Kotler \& Keller (2012) chamam de níveis de canal, onde utiliza-se a quantidade de intermediários para definir a extensão de um canal.

Conforme a figura 2, que representa os canais de marketing de bens e consumo, todos os quatro níveis possuem fabricante e consumidor em seus extremos. No nível zero (ou canal de marketing direto), o fabricante vende diretamente para o consumidor final. No nível um, há um único intermediário, como o varejista. No nível dois, geralmente há um varejista e um atacadista e no nível três é o mais completo, que além dos citados, há um atacadista especializado (KOTLER \& KELLER, 2012). 
Nível Zero

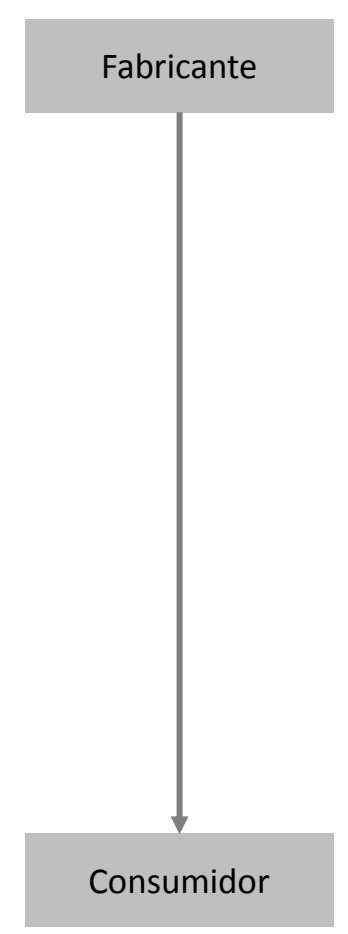

Nível 1

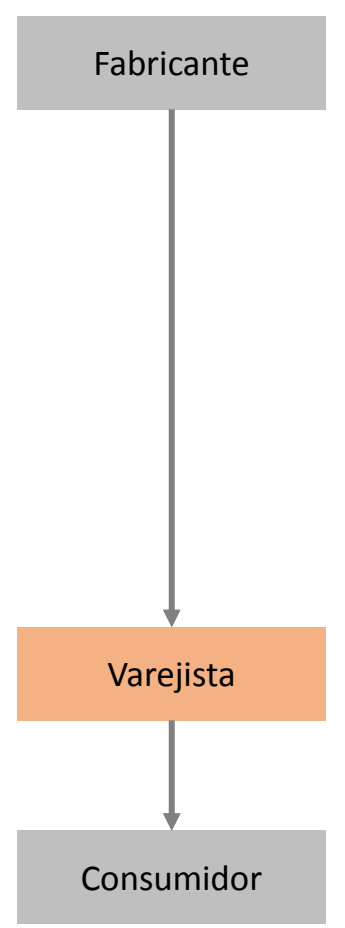

Nível 2

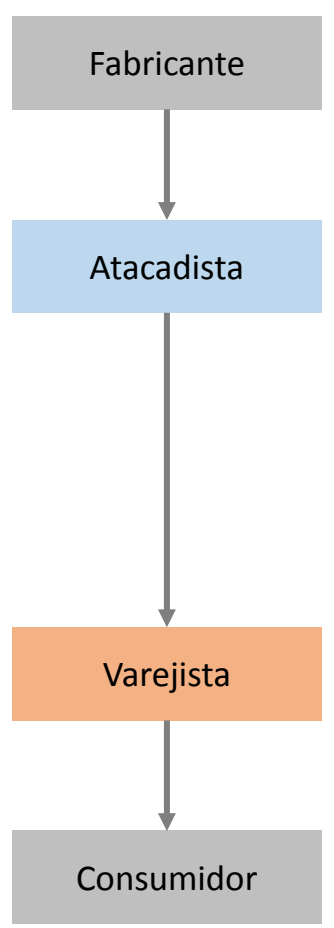

Nível 3

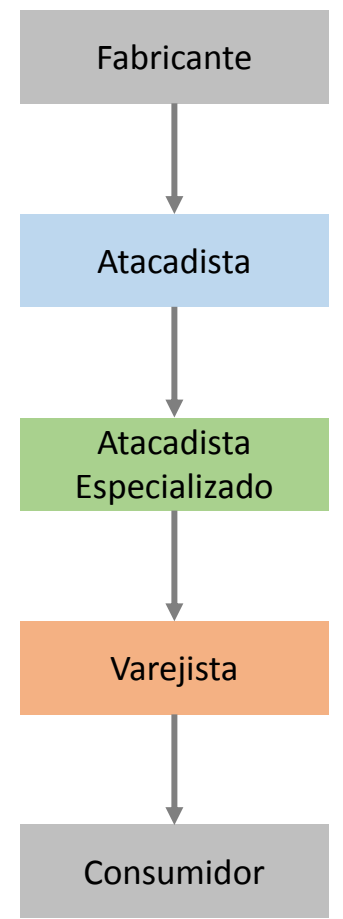

Fonte: Kotler \& Keller, 2012, adaptado.

Figura 2 - Canais de marketing de bens de consumo

Rosenbloom (2011) afirma que, o "P" do composto de marketing que corresponde os canais de distribuição (praça), era o que menos recebia atenção comparado aos outros "Ps" - produto, preço e promoção. Ou seja, era considerado algo secundário perante os outros conceitos mencionados.

Entretanto, o autor salienta cinco tendências que conduziram uma mudança de pensamento nos últimos anos. Por consequência, muitas empresas têm empenhado muitos esforços nos canais de distribuição.

A primeira tendência diz respeito a uma maior dificuldade em conquistar uma vantagem competitiva sustentável. Ou seja, uma vantagem difícil de ser copiada pela concorrência. É árduo conseguir com produto (fácil cópia dos atributos pelos concorrentes), preço (muito difícil ter uma larga vantagem devido as mudanças tecnológicas que padronizam preços) e promoção (mesmo que uma comunicação seja memorável, o efeito torna-se efêmero diante de outras milhares que bombardeiam os consumidores). Já a estratégia de canal é de longo prazo, geralmente exige uma estrutura e é baseada em pessoas e relacionamentos. 
A segunda ressalta o poder crescente dos distribuidores, especialmente os varejistas, nos canais de marketing. Afinal, hoje em dia, percebe-se uma mudança de força entre os produtores para os distribuidores. Poderosos varejistas, como Wal-Mart tornaram-se protagonistas porque respondem por grande parcela da linha de commodities, o que faz controlar o mercado. Ou seja, traçar estratégias de canais torna-se fundamental para produtores e fabricantes.

A terceira fala da necessidade de reduzir custos de distribuição. Pois, esses custos representam significativamente no preço final do produto, às vezes são mais altos do que os custos de fabricação ou de matéria-prima. Logo, a estratégia de canal é novamente requisitada porque é necessário reduzir os custos e proporcionar a demanda certa, sem faltar ou sobrar em excesso para o consumidor, além dos processos que serão implementados.

A quarta é sobre a revalorização do crescimento. Na década de 1990, a ideia geral das empresas americanas era reduzir custos. Mas, em determinado momento, parecia ter chegado a um limite. Com isso, a ideia de crescimento voltou à tona. Mas um crescimento rápido é difícil, ainda mais para produtos maduros, com mercados maduros e economias de baixo crescimento. Com isso, conquistar market share era uma boa saída. E a ligação com a estratégia de canal é que concentrar esforços de distribuidores e revendedores nos produtos de uma empresa em particular e aumenta o market share e as vendas da empresa.

E, por fim, a quinta tendência diz respeito ao crescente papel da tecnologia. Afinal, a tecnologia impacta praticamente todas as áreas de uma empresa, inclusive a distribuição. Porém, a tecnologia em particular, defendida pelo autor, é a internet. Pois, qualquer produtor está conectado com centenas de milhões de clientes potenciais, e assim realizar transações comerciais com eles. Seja como for, a internet não pode ser ignorada como uma forma de distribuição.

Após esse breve panorama dos motivos que envolvem o aumento da importância do canal de marketing como estratégia, torna-se necessário estender o conceito de canal de marketing. Rosenbloom (2011) utiliza um conceito do ponto de vista da tomada de decisão, e como ele deve ser visto pelo gerente de marketing. Ele define o canal como "organização contratual externa que a administração opera para alcançar seus objetivos de distribuição" (ROSENBLOOM, 2011, p. 27).

O termo "externa" refere-se que o canal existe fora da empresa, não é algo da estrutura interna. Ou seja, ocorre uma gestão interorganizacional (administrar mais de uma empresa) em vez de intraorganizacional (que é apenas uma). 
O termo "organização contratual" envolve a negociação à medida que o produto ou serviço move-se do produtor para o consumidor final. Ou seja, comprar, vender e transferir a propriedade de bens e serviços.

O termo "opera" diz respeito ao envolvimento da administração nos negócios do canal. Quando a administração opera a organização contratual externa, ela tomou a decisão de não deixar a organização funcionar por conta própria.

E o termo "objetivo de distribuição" significa que a administração traçou metas de distribuição que serão alcançadas por meio dos canais de marketing.

As inovações tecnológicas alteraram a relação entre os consumidores finais e os donos dos direitos autorais. As empresas ligadas a música perceberam que não adianta brigar, processar ou fazer qualquer ação que mude a atual realidade da indústria fonográfica (KRETZER \& TOYAMA, 2008).

Assim, muitas empresas se renderam a música digital e também começaram a investir em soluções tecnológicas de proteção as músicas. $E$ vender música digital promove novas atividades por novas empresas. Afinal, exige novas formas de distribuição, pagamento e marketing (Kretzer \& Toyama, 2006). Por isso, serão examinadas as mídias físicas e digitais separadamente.

\subsubsection{Mídias físicas}

Borges (2011) define como mídias físicas (para músicas) os CDs, DVDs, LPs e fitas K7. O autor engloba o conceito de mídias físicas com o conceito de suportes físicos. Nesse caso, envolveria também o pen drive, computador e celular. Afinal, apesar de terem funcionalidades próprias, eles funcionam como suporte de música que possibilitam carregar ou dar para alguém, independente do formato que o arquivo esteja. Mas, esse tópico foca apenas nas mídias físicas originais, sem inferir diretamente nos meios de execução das mídias físicas.

Kretzer \& Toyama (2008) utilizam uma adaptação do modelo promovido pela Organisation for Economic Co-operation and Development (OECD, 2005) para ilustrar como é a rede de distribuição de mídias físicas de música (figura 3). Nesse caso, o e-commerce não se refere às mídias digitais, e sim, aos formatos físicos vendidos pela internet, como CDs, DVDs e Vinis. 


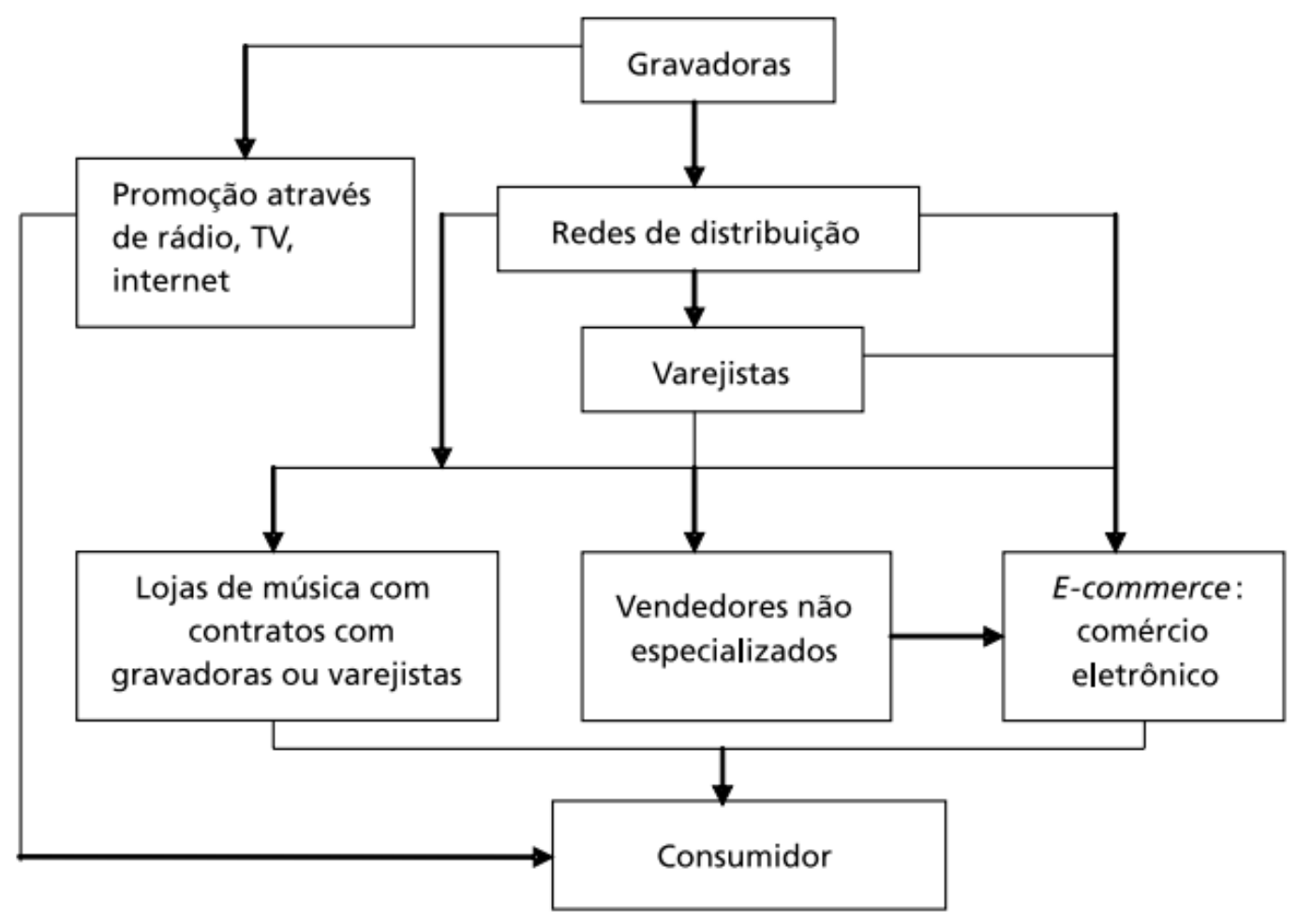

Fonte: Kretzer \& Toyama, 2008 - Adaptado de OECS, 2005.

\section{Figura 3 - Rede de distribuição das mídias físicas}

Kotler \& Keller (2012) definem e-commerce como a utilização de um site para realizar troca de bens e serviços pela internet. As principais vantagens são a diminuição de custos fixos e a possibilidade de lucro com a venda de baixo volume de produtos.

Em 2008, os autores Kretzer \& Toyama (2008) afirmaram que a indústria fonográfica era basicamente oligopolista porque havia uma concentração de poder em apenas quatro empresas - as gravadoras Sony BMG, EMI, Universal e Warner. O restante do mercado era composto por muitas e pequenas empresas, que se dedicaram a nichos de mercados voltados para músicas independentes, como a brasileira Biscoito Fino que atua com Música Popular Brasileira (MPB).

Era comum, entre as pequenas gravadoras, não conseguirem cumprir todas as etapas de gravar e comercializar mídias físicas, principalmente porque era muito caro. Diante dessa dificuldade, recorriam a acordos com as grandes gravadoras, e assim, estas ainda tinham influência sobre o mercado independente (KRETZER \& TOYAMA, 2008).

Todavia, com ajuda da tecnologia, esse cenário está em mudança. Hoje em dia não é necessário dispender grandes quantias dinheiro para arcar com 
aparelhos de produção musical. Um exemplo é o Digital Music Workstation (DAW), que revolucionou a indústria de gravação, por permitir a transformação de um áudio analógico em digital por um baixo custo. Além disso, há formas mais baratas de se comunicar com o público, como as redes sociais. Assim, a tecnologia permite uma grande oportunidade para as gravadoras pequenas - a liberdade (KRETZER \& TOYAMA, 2008).

\subsubsection{Mídias digitais}

Kretzer \& Toyama (2008) afirmam que as mudanças tecnológicas permitiram grandes impactos nas formas de distribuição de música. Assim, os autores informam que as vendas de mídias digitais se dão de três maneiras: (1) downloads de músicas ou álbuns inteiros, (2) serviços de assinatura e (3) por softwares de compartilhamento.

A primeira maneira seria o iTunes, por exemplo. Afinal, por meio do site ou aplicativo, o consumidor pode comprar tanto o álbum completo, como apenas as músicas individuais que deseja, totalmente online e em formato digital (GENES, CRAVEIRO \& PROENÇA, 2012).

Há dois conceitos de distribuição nesse exemplo do iTunes, um é o ecommerce, que já foi definido anteriormente, que serve tanto para mídias físicas, como também digitais. E o outro é o m-commerce, que Kotler \& Keller (2012) classifica como semelhante ao e-commerce, tendo como principal diferença a possibilidade de comprar apenas pelo smartphone.

A segunda maneira poderia ser representada pelos streamings. Afinal, suprem a necessidade de ouvir músicas sem precisar adquirir, nem mesmo, um material digital - não há necessidade de baixar e armazenar. O Youtube, por exemplo, tornou-se um ótimo player não só para quem quer assistir a videoclipes, como também ouvir os áudios de músicas (GENES, CRAVEIRO \& PROENÇA, 2012).

Por fim, um exemplo da terceira maneira poderia ser o acordo entre o Kazaa e o Cornerbans.com que distribuem downloads seguros de artistas emergentes por meio de software peer to peer - compartilhamento de arquivos, mas dessa vez, de forma legal. (KRETZER \& TOYAMA, 2008). 


\subsection{Comportamento geracional}

Entender o comportamento geracional é vital porque "a época em que um consumidor cresce, há um elo cultural com os outros milhões que ficam adultos no mesmo período" (Solomon, 2011, p. 540). Schewe, Meredith \& Noble (2000) corroboram com esse pensamento por informar que os Coortes (segmentos geracionais) são influenciados por eventos externos, que estavam acontecendo enquanto um grupo tornava-se maior de idade (por volta dos 17 e 23 anos). Ou seja, as experiências compartilhadas distinguem um Coorte de outro.

Por esse motivo, serão abordados aspectos que diferenciam as gerações $\mathrm{X}$ e $\mathrm{Y}$ no comportamento de consumo.

\subsubsection{Geração $X$}

Solomon (2011) utiliza o Coorte de idade de pessoas nascidas entre 1965 e 1985 como sendo da geração X. Antes de entrar em detalhes sobre essa geração, vale a apresentação do contexto promovido pelos autores Schewe \& Meredith (2004), que falam de Coorte de idades em nível global e local, no Brasil.

Os autores começam por informar que grandes acontecimentos como $A$ Grande Depressão, a Segunda Guerra Mundial e a Guerra Fria foram exemplos de moldes para países como Estados Unidos e Reino Unido, já que possuem laços históricos e culturais semelhantes (SCHEWE \& MEREDITH, 2004).

Porém, como o Brasil não teve uma participação muito ativa na Segunda Guerra Mundial, esse não foi considerado um evento definidor na nossa sociedade, como foi para a maioria dos países. Já, para a Rússia, representou um Coorte de doze anos, porque esse momento histórico resultou em vinte e três milhões de mortos, com consequências que duraram muitos anos. Ou seja, diferentes culturas e histórias possuem Coortes distintos, assim como, quando são parecidas, tendem a não mudar muito (SCHEWE \& MEREDITH, 2004).

Por isso, os supracitados autores fizeram uma análise baseada nos Coortes do Brasil. Porém, esse trabalho abordará apenas o que corresponde aos anos aproximados ao que Solomon chama de Geração X, para entender o contexto em que nasceu esse grupo etário. Seguido disso, ter-se-á as conclusões dos pesquisadores e as implicações de marketing para esse grupo.

A tabela 1 indica o Coorte: ano de nascimento, evento definidor e chaves de valores. Este trabalho irá discorrer sobre os Coortes (1) Década Perdida e (2) 
Liberdade, que correspondem à faixa de nascimentos definidas por Solomon (SCHEWE \& MEREDITH, 2004).

\begin{tabular}{|l|l|l|l|}
\hline \multicolumn{1}{|c|}{ Coorte } & \multicolumn{2}{c|}{ Evento Definidor } & Valores da Chave de Coorte \\
\hline Eva Vargas & $1913-1928$ & $\begin{array}{l}\text { Nacionalismo } \\
\text { Estado como uma solução } \\
\text { Ser é melhor do que ter } \\
\text { Aceitação da autoridade }\end{array}$ \\
\hline Pós-guerra & $1929-1937$ & $\begin{array}{l}\text { Deposição de Vargas } \\
\text { Dutra para presidente }\end{array}$ & $\begin{array}{l}\text { Tradição moral } \\
\text { Valor de ter }\end{array}$ \\
\hline Otimismo & $1938-1950$ & $\begin{array}{l}\text { Suicídio de Vargas } \\
\text { Kubitschek como presidente }\end{array}$ & $\begin{array}{l}\text { País do futuro } \\
\text { Cultura jovem e olhar no exterior }\end{array}$ \\
\hline Ano de Ferro & $1951-1962$ & $\begin{array}{l}\text { Instituição da Ditadura } \\
\text { Crise social } \\
\text { Instituição do Al5 }\end{array}$ & $\begin{array}{l}\text { Beligerante } \\
\text { Alienação, silêncio } \\
\text { Mito da grandiosidade } \\
\text { Valor da educação }\end{array}$ \\
\hline Década Perdida & $1963-1974$ & $\begin{array}{l}\text { Anistia para militares } \\
\text { Fim do crescimento econômico }\end{array}$ & $\begin{array}{l}\text { Medo } \\
\text { Frustração } \\
\text { Materialismo } \\
\text { Individualismo }\end{array}$ \\
& 1975 e depois & $\begin{array}{l}\text { Crise do Governo } \\
\text { Impeachment do Collor } \\
\text { Mudança da moeda para o real }\end{array}$ & $\begin{array}{l}\text { Autossuficiência } \\
\text { Consumismo } \\
\text { Recupeação dos valores éticos e morais }\end{array}$ \\
\hline Liberdade & &
\end{tabular}

Fonte: Shewe \& Meredith, 2004, tradução nossa.

\section{Tabela 1 - Coortes no Brasil}

O Coorte "Década Perdida" possui como momentos definidores a anistia para mititares e o fim do crescimento econômico. Com isso, valores como medo, frustração, materialismo, individualismo e falta de esperança marcaram esse primeiro Coorte, dentro do definido pelo Solomon, como $X$ (SCHEWE \& MEREDITH, 2004).

Diante desses valores, os autores sugeriram implicações de marketing para esse grupo, como: enfatizar produtos de moda e usuários de moda, produtos de valor que podem beneficiar a individualidade de seus usuários, deixar claro que é algo que todo mundo possui e utilizar porta-vozes com alta visibilidade que possam transmitir uma imagem de honestidade (SCHEWE \& MEREDITH, 2004).

Já o Coorte "Liberdade" diz respeito a crise do governo, o impedimento do presidente Collor e a mudança da moeda, para o real. Assim, valores como autossuficiencia, consumimo e recuperação dos valores éricos e morais tornaram-se destaque (SCHEWE \& MEREDITH, 2004).

Com isso, as implicações de marketing envolvem: recorrer a produtos feitos sob medida para apelar para esse grupo, usar temas globais em 
promoções, evitar apelos eróticos, utilizar promoções associados com valores de honestidade e desenvolver mecanismos favor que permitem a negociação, como estrutura variável (SCHEWE \& MEREDITH, 2004).

Ademais, de acordo o estudo sobre o comportamento do consumidor de música digital de Martins (2012), pessoas por volta dos quarenta e quatro anos são menos propensas a utilizar músicas digitais, por não saberem ou não possuírem tempo para aprender a utilizar mecanismos mais tecnológicos. Apesar disso, já utilizam a internet com mais frequência, seja em casa ou no trabalho. Trata-se de um público que ainda compra mídias físicas, como CDs. Já os respondentes um pouco mais jovens, mas não suficiente para sair do Coorte relacionado à geração $X$, utilizam o formato digital para ouvir música e estão dispostos a pagar por elas $\mathrm{R} \$ 1,09$ por faixa na internet, em média, já que, perceberem como ilegal o consumo por outras vias que não sejam pagas. Além disso, costumam comprar online, possuem velocidade maior de conexão à internet e utilizam o smartphone para acessá-las. Outro motivo de quererem remunerar os serviços de música é pela facilidade de não precisar se aprofundar em conhecimentos de informática porque acham que pagar é mais seguro (MARTINS, 2012).

\subsubsection{Geração $Y$}

Segundo Solomon (2011), a geração Y, também conhecida como Millenials e Echo Boomers, são pessoas nascidas entre os anos de 1984 e 2002. Esse grupo etário é caracterizado por "manter uma perspectiva positiva da vida" (Solomon, 2011, p. 544) e possuir algumas palavras que os define, como: mudança, novo, progresso, esperança e entusiasmo.

Os Millenials nasceram em um momento de profundas transformações nas vidas dos norte-americanos. Inclusive, trata-se de pessoas que cresceram em lares não tradicionais - seja por terem sido criados apenas por um dos pais ou por terem a mãe no mercado de trabalho. Os membros dessa geração são considerados "malabaristas" por valorizarem a liberdade e ao mesmo tempo serem apegados aos pais (SOLOMON, 2011).

A grande marca dos Echo Boomers é o fato de ser a primeira geração a crescer com computadores dentro de casa. Diante disso, o autor caracteriza essas crianças como "digitais de nascença", já que, cresceram nesse ambiente tecnológico e, por isso, utilizam internet demasiadamente - smartphones, mensagens de textos ao invés de serviços voz, assistência de vídeos e outras 
atividades cotidianas envolvendo tecnologia são alguns dos meios utilizados. Esses jovens proporcionam uma extensa geração de conteúdo online, devido às redes sociais e blogs. Com isso, boca-a-boca positivos e negativos são proliferados como nunca antes (SOLOMON, 2011).

Martins (2012) constatou com sua pesquisa sobre o consumidor de música digital brasileiro que jovens entre 18 e 35 anos (que se enquadram parcialmente a essa geração) são os mais adeptos ao consumo de música digital. O autor justifica tal fato à facilidade em utilizar e comprar pela internet. Ele ainda contribui com a informação de que esse grupo abandonou o hábito de compra de mídias físicas, como CD's, por terem facilidades maiores ao ouvir no MP3 player ou smartphone.

Em termos gerais, a amostra utilizada indicou que esses respondentes não utilizam lojas oficiais para o consumo de música, mas, ao mesmo tempo, não consideram como algo ilegal. Apesar disso, grande parte possui intenção de pagar futuramente (MARTINS, 2012).

As empresas também precisam ter cuidados especiais ao se comunicar com esse grupo etário. Afinal, a geração $Y$ exige mensagens com autenticidade e sem condescendência. Ou seja, não seria interessante provocá-los com propagandas enganosas porque eles tendem a descobrir mais facilmente e propagar por meio de suas redes sociais, por exemplo (SOLOMON, 2011).

Solomon (2011) lista quatro regras de como se comunicar com os Millenius. A primeira é com relação a não falar com superioridade, já que, eles precisam sentir que estão chegando às suas próprias conclusões. Então dizer o que eles precisam ou não fazer não é interessante. A segunda é não tentar ser o que não é, pois, esses jovens valorizam a fala direta. A terceira regra é divertilos, ser interativos e não se prolongar nas vendas porque eles gostam de descobrir novas perspectivas, pois, se acharem interessante algo, eles irão procurar mais informações. E a última regra diz respeito a mostrar que sabe o que eles estão passando, mas de uma forma leve.

\subsection{Envolvimento do consumidor}

Solomon (2011) afirma que as pessoas podem ficar muito apegadas a certos produtos e até marcas. Porém, o grau de motivação é diferente de uma pessoa para outra. Há algumas que não conseguem viver sem o último lançamento tecnológico de determinado periférico enquanto outras ficam plenamente satisfeitas com produtos mais simples. 
Por isso, é importante entender o conceito de envolvimento, que é a relevância que o consumidor percebe com base em suas próprias necessidades, valores e interesses para produtos, marcas, anúncios ou situações de compra (SOLOMON, 2011).

Os níveis de envolvimento são diferentes para cada consumidor: desde a inércia, que indica falta de interesse nos estímulos de marketing e menor motivação para busca de alternativas, até a paixão, que são os obcecados por produtos que possuem real significado para elas (SOLOMON, 2011).

Corrobora-se com o nível da paixão o conceito de produtos cult, que são relacionados a marcas em que consumidores possuem lealdade incondicional e até devoção, como a Apple, em que pessoas enfrentam dias em uma fila para serem os primeiros a comprar, apesar de possuir compra facilitada pela internet (SOLOMON, 2011).

O envolvimento pode adquirir diferentes formas. Ele pode ser cognitivo, quando a pessoa sente a necessidade de aprender tudo sobre as especificações de um determinado produto, ou emocional, quando há um sentimento envolvido, como sentir um arrepio enquanto observa determinado produto com significado especial e afetivo (SOLOMON, 2011).

O autor pondera que o envolvimento é um conceito sem precisão porque depende de outras coisas e resulta em significados diferentes para cada pessoa. Todavia, ele revela que há tipos mais amplos de envolvimento, que são relacionados ao produto, à mensagem-resposta ou a situação de compra. $\mathrm{O}$ envolvimento com o produto está relacionado ao nível de interesse da pessoa por algum produto. Já o envolvimento mensagem-resposta seria a forma que são utilizadas as plataformas de mídia e o envolvimento com a situação de compra diz respeito a forma como determinados produtos iguais são vendidos em diferentes situações (SOLOMON, 2011).

\subsection{Eu estendido}

De acordo com Solomon (2011), o conceito de eu estendido trata de pessoas que consideram objetos externos como parte delas. Há culturas, inclusive, que incorporam tais produtos de forma ainda mais extrema, como o caso de indivíduos que são enterrados com seus bens preferidos. Ou seja, tais pessoas valorizam suas posses como parte delas.

Devido à importância desse conceito, o autor aborda o eu estendido em quatro níveis: individual, familiar, comunitário e de grupo. Eles variam de objetos 
pessoais até em "coisas que possibilitam que sintam como se estivessem enraizadas em seus ambientes sociais mais amplos" (SOLOMON, 2011, p. 204).

A frase "você é o que você usa" é bem aplicada ao nível individual, em que os consumidores incluem bens pessoais para se definirem. O nível familiar indica a casa e móveis como o eu estendido, já que, a casa é vista como aspecto central da identidade. No nível comunitário os consumidores se descrevem em termos da sua terra natal. E por fim, no nível de grupo, refere-se a ligações com grupos sociais, como equipes esportivas (SOLOMON, 2011).

\subsection{Influências no comportamento do consumidor}

De acordo com Kotler \& Keller (2012), o comportamento do consumidor é influenciado por fatores culturais, sociais e pessoais.

Os fatores culturais são fundamentais na determinação de desejos e comportamentos, já que, pessoas que nascem nos diferentes países possuem influências e valores distintos. Além disso, as empresas precisam verificar quando as subculturas crescem e se tornam influentes, que podem ser subculturas raciais, religiosas, geográficas e outras, que fornecem identificação e socialização (KOTLER \& KELLER, 2012).

Kotler \& Keller (2012) afirmam que os fatores sociais são categorizados entre grupos de referência, família, papéis sociais e status. Os grupos de referência são aqueles que influenciam direta (grupos de afinidade) ou indiretamente o comportamento do consumidor. Há ainda a diferença entre grupos primários (interação de modo contínuo e informal) e secundários (grupos mais formais e exige menos interação contínua).

A família é classificada pelos autores Kotler \& Keller (2012) como a organização de compra mais importante na sociedade. E esse grupo primário possui uma distinção: família de orientação (pais e irmãos) e procriação (cônjuge e filhos).

Já os papéis e status são referentes à posição de uma pessoa dentro dos diversos grupos que ela participa. Sendo o papel a atividade esperada da pessoa naquele contexto, que implica em um status comparativo com outros integrantes do grupo (KOTLER \& KELLER, 2012).

Por fim, os fatores pessoais são influenciados pela idade e estágio no ciclo de vida, ocupação e circunstâncias econômicas, personalidade e autoimagem e estilo de vida e valores (KOTLER \& KELLER, 2012). 


\subsection{Marketing nostálgico}

Solomon (2011) descreve a nostalgia como um passado visto com tristeza e saudade. Ou seja, as marcas que possuem produtos, considerados clássicos, apelam para as recordações da juventude dos consumidores.

Gomes, Azevedo \& Peçanha (2014) englobam como nostálgico as criações novas, como a linha retrô de eletrodomésticos da Brastemp; produtos autênticos, que são encontrados em antiquários e mostras de carros antigos, por exemplo; objeto vintage, que mesmo antigo, tornou-se valioso por questões estéticas; as réplicas, copiadas fielmente, sendo mais baratas que as originais; e as antiguidades, que são mais velhas que os objetos vintages e encontradas em museus.

Fleck (2008) afirma que elementos nostálgicos podem estar presentes em diversos produtos, desde o produto em si até a embalagem. Entretanto, se for visto pelas campanhas de publicidade, vira quase uma totalidade. Afinal, quase todos os produtos comercializados podem comunicar-se com os consumidores por despertar o lado emocional da lembrança.

Todavia, o estudo Design Retrô e Marketing do Saudosismo amplia o conceito de Solomon (2011) por relacionar a nostalgia a uma "romantização do passado", não só para quem viveu literalmente um determinado período de tempo, mas também, quem teve acesso a ele, por meio da internet, por exemplo (GOMES, AZEVEDO \& PEÇANHA, 2014, p.18).

Os autores afirmam que, devido à dificuldade de se diferenciar dos seus concorrentes, muitas empresas realizam apelos nostálgicos para trazer conforto, funcionalidade e segurança por meio de produtos retrô. Afinal, a tecnologia tem tornado os produtos, em termos funcionais, cada vez mais semelhantes. E produtos em períodos anteriores são considerados confiáveis, duráveis e originais, pelos consumidores (GOMES, AZEVEDO \& PEÇANHA, 2014).

Por isso, as empresas aproveitam esse movimento do consumidor querer reviver (ou viver) o passado, por meio de produtos com tecnologias atuais e características físicas baseadas em outras épocas. As empresas, por sua vez, buscam cada vez mais uma diferenciação dos ativos intangíveis. Ou seja, não apenas por satisfazer necessidades utilitárias (funcionais), mas também hedônicas (emocionais) e assim, diferenciar-se (GOMES, AZEVEDO \& PEÇANHA, 2014). 


\subsection{Renda discricionária}

Solomon (2011) afirma que a demanda de bens e serviços depende de duas variáveis - a possibilidade e a disposição para comprar. Afinal, produtos necessários tendem a ter uma demanda estável, enquanto outros podem ser diminuídos ou eliminados, dependendo da situação do indivíduo.

Com isso, surge o conceito de renda discricionária, que segundo o autor Churchill (2013), trata-se do dinheiro que resta para os consumidores gastarem depois do pagamento de despesas essenciais e impostos (Churchill, 2013). O autor facilita o entendimento por relacionar a renda discricionária como sendo o dinheiro extra que torna a vida mais divertida. Pois, é com essa renda que se paga férias, hobbies, lazer, música, decoração e outros. 


\section{Métodos e procedimentos de coleta e de análise de dados do estudo}

Este capítulo pretende informar sobre as diversas decisões acerca da forma como este estudo foi realizado.

Está dividido em cinco seções que informam, respectivamente, sobre as etapas de coleta de dados do estudo realizado e sobre as fontes de informação selecionadas para coleta de informações. Na sequência, informa-se sobre os processos e instrumentos de coleta de dados realizados em cada etapa, com respectivas justificativas, sobre as formas escolhidas para tratar e analisar os dados coletados e, por fim, sobre as possíveis repercussões que as decisões sobre como realizar o estudo impuseram aos resultados assim obtidos.

\subsection{Etapas de coleta de dados}

Esse é um estudo exploratório, pois segundo Gil (2007), temas pouco pesquisados e genéricos devem ser abordados dessa forma, por indicarem oportunidades para investigações mais profundas. Além disso, tendem a envolver estudos bibliográficos e entrevistas não padronizadas.

A coleta de dados foi realizada através de estudo bibliográfico e pesquisa de campo qualitativa. O estudo bibliográfico consiste de pesquisa de dados secundários sobre o tema livros e artigos científicos. Gil (2007) salienta que uma das vantagens do estudo bibliográfico é o alcance de um escopo maior de informações. A pesquisa de campo contemplou um público restrito dentro do universo de consumo de música através de entrevistas em profundidade,

\subsection{Fontes de informação selecionadas para coleta de dados}

$\mathrm{Na}$ primeira etapa buscou-se informações junto a livros e artigos científicos. Tais dados secundários foram fundamentais para corroborar com 0 estilo de estudo bibliográfico que permeia esse momento do trabalho. Para isso, foram consultados autores consagrados do marketing - como Kotler, Keller, Solomon, Churchill e outros. Além de diversos artigos encontrados na base de artigos da Fundação Getúlio Vargas (FGV) e no Google Acadêmico. Essas 
fontes secundárias foram úteis para cruzar com os resultados da segunda etapa e formular a conclusão do trabalho.

Por fim, esta segunda etapa foi composta de dados primários por meio de coleta de opiniões de consumidores de música nas gerações $\mathrm{X}$ e $\mathrm{Y}$. A forma de recrutar tais pessoas foi por conveniência, durante os meses de março e abril de 2016. Tal forma é definida por Gil (2007) como a menos rigorosa de todos os tipos de escolha de respondentes, já que, o pesquisador os seleciona por possuir maior acessibilidade.

Foram dezesseis entrevistados (Tabela 2), sendo oito da Geração X e oito da $\mathrm{Y}$. Não foram realizadas mais entrevistas, pois chegou-se a um número considerável para uma pesquisa qualitativa de cunho exploratório - mesmo não havendo esgotamento do tema.

\begin{tabular}{|c|c|c|c|c|c|c|}
\hline \multicolumn{7}{|c|}{ GERAÇÃO $X$} \\
\hline $\mathbf{N}$ & Sexo & Escolaridade & Cidade & Nascimento & Renda & Entrevista \\
\hline $\mathrm{X} 1$ & Masculino & Superior Completo & Rio de Janeiro, RJ & 1972 (44 anos) & B2 $(4.427,36)$ & Presencial \\
\hline$\times 2$ & Feminino & Superior Completo & Rio de Janeiro, RJ & 1978 (38 anos) & $A(20.272,56)$ & Presencial \\
\hline $\mathrm{x} 3$ & Feminino & Superior Completo & Rio de Janeiro, RJ & 1974 (42 anos) & B1 $(8.695,88)$ & Presencial \\
\hline$X 4$ & Feminino & Superior Completo & Rio de Janeiro, RJ & 1976 (40 anos) & B2 $(4.427,36)$ & E-mail \\
\hline $\mathrm{X5}$ & Feminino & Superior Completo & Rio de Janeiro, RJ & 1972 (44 anos) & $A(20.272,56)$ & Telefone \\
\hline $\mathrm{X6}$ & Masculino & Superior Completo & Belo Horizonte, MG & 1984 (32 anos) & B2 $(4.427,36)$ & Skype \\
\hline $\mathrm{X7}$ & Feminino & Superior Completo & Rio de Janeiro, RJ & 1980 (36 anos) & B1 $(8.695,88)$ & Telefone \\
\hline $\mathrm{x} 8$ & Feminino & Superior Incompleto & Rio de Janeiro, RJ & 1970 (46 anos) & B2 $(4.427,36)$ & Presencial \\
\hline \multicolumn{7}{|c|}{ GERAÇÃO Y } \\
\hline $\mathbf{N}$ & Sexo & Escolaridade & Cidade & Nascimento & Renda & Entrevista \\
\hline Y1 & Feminino & Superior Incompleto & Rio de Janeiro, RJ & 1992 (24 anos) & $\mathrm{A}(20.272,56)$ & Presencial \\
\hline $\mathrm{Y} 2$ & Feminino & Superior Incompleto & Rio de Janeiro, RJ & 1994 (22 anos) & $\mathrm{A}(20.272,56)$ & Presencial \\
\hline Y3 & Feminino & Superior Incompleto & Rio de Janeiro, RJ & 1988 (28 anos) & B1 $(8.695,88)$ & Presencial \\
\hline Y4 & Masculino & Superior Incompleto & Rio de Janeiro, RJ & 1986 (30 anos) & B2 $(4.427,36)$ & Skype \\
\hline Y5 & Masculino & Superior Incompleto & Rio de Janeiro, RJ & 1992 (24 anos) & B2 $(4.427,36)$ & Presencial \\
\hline Y6 & Masculino & Superior Incompleto & Gov. Valadares, MG & 1990 (26 anos) & B1 $(8.695,88)$ & Skype \\
\hline Y7 & Masculino & Superior Completo & São Paulo, SP & 1990 (26 anos) & B2 $(4.427,36)$ & Skype \\
\hline Y8 & Masculino & Superior Incompleto & Rio de Janeiro, RJ & 1990 (26 anos) & $\mathrm{A}(20.272,56)$ & Skype \\
\hline
\end{tabular}

Fonte: Autoria própria

\section{Tabela 2 - Entrevistados}

Observa-se que a idade mencionada na tabela 2 é referente ao ano de 2016, baseado no nascimento. Além disso, todas as rendas concentraram-se nos cortes A, B1 e B2, que significa dizer que nenhum dos entrevistos possui renda média inferior a $R \$ 4.427,36$. A maior parte das entrevistas foi realizada pessoalmente, sendo uma por e-mail, duas por telefone e cinco por Skype. As entrevistas de moradores fora da cidade do Rio de Janeiro foram possíveis por meio de tentativas de captar pessoas em grupos relacionados à música na rede 
social Facebook. O grupo onde estavam esses três entrevistados chama-se "Vinil e LP's Colecionadores".

\subsection{Procedimentos e instrumentos de coleta de dados utilizados}

As informações de campo foram colhidas por meio de entrevistas em profundidade. De acordo com Gil (2007), as entrevistas são uma forma de interação social, em que o entrevistador formula perguntas ao entrevistado em busca de dados que colaborem com o problema de estudo.

Uma das vantagens levantadas pelo autor é a possibilidade de o entrevistador esclarecer dúvidas que apareçam durante a entrevista e se adaptar ao entrevistado e as circunstâncias, diferente de questionários fechados que não levantam outras questões, que podem tornar-se dados importantes. Além disso, pode-se perceber a expressão corporal e gestos em geral.

O roteiro das entrevistas foi criado a partir do conceito de entrevista focalizada. Que segundo Gil (2007), trata-se de um estilo de roteiro semiestruturado e quase informal. Mas, por possuir um tema específico, quando o entrevistado se desviar do foco, o entrevistador precisa intervir de forma sutil para respeitar o interesse temático. O roteiro encontra-se no Anexo 1.

Ademais, para não perguntar diretamente a renda da pessoa e ter dados mais confiáveis, utilizou-se o Critério Brasil ABEP 2015 (Anexo 2), que, por meio de um questionário sobre os bens que o consumidor possui, foi possível enquadrar os entrevistados em uma das faixas de renda do critério da Associação Brasileira de Empresas de Pesquisa (ABEP).

\subsection{Formas de tratamento e análise dos dados coletados}

As informações coletadas foram tratadas por meio de análise de conteúdo. Segundo Bardin (1977), esta forma de tratar os dados coletados permite que o pesquisador os transforme em categorias que tornam mais fáceis a análise. Além disso, o autor salienta três etapas básicas: pré-análise, exploração do material e tratamento dos dados e interpretação.

A autora Vergara (2012), auxilia na forma de utilizar tal método. Os passos iniciais são definir o problema de estudo, fazer revisão da literatura, definir os meios para coleta de dados e executar tal coleta. Essas ações foram desenvolvidas durante os tópicos anteriores, exceto a de execução da coleta. Esses pré-requisitos formam o que Bardin (1977) definiu como pré-análise e 
exploração do material. Sendo o primeiro a definição e o segundo a implementação de tais procedimentos.

Após a pesquisa de campo, as entrevistas foram transcritas para servir de estudo principal de análise. Foram definidas as unidades e categorias, e por fim, a análise de conteúdo foi realizada por apoio ao procedimento interpretativo. As transcrições foram separadas pelas categorias, para facilitar o processo de análise. Além disso, uma tabela realizada no Excel foi fundamental para emparelhar as dez mídias citadas no roteiro com os principais pontos dos dezesseis entrevistados. Assim, foi possível cruzar as principais transcrições e ter um mapa visual facilitador para esta análise. Ao utilizar este método foi possível colorir e colocar anotações simples, como o perfil de cada entrevistado. Além disso, utilizou-se nuvens de palavras para uma primeira análise nas três primeiras categorias.

O passo seguinte foi resgatar o problema de pesquisa com o propósito de comparar o que foi coletado em campo com o referencial teórico. Esse emparelhamento foi possível a partir de um resumo simples manuscrito com os principais pontos levantados pelos autores do capítulo dois. Por fim, foi realizada a interpretação, que compreende a análise dos dados à luz dos objetivos estabelecidos na pesquisa.

\subsection{Limitações do método}

Zikmund (2006) salienta que a pesquisa exploratória não substitui uma pesquisa conclusiva quantitativa. Como a maioria das exploratórias são qualitativas, a interpretação é feita por julgamento. Por isso, o autor sugere a realização de um estudo quantitativo com uma amostra representativa para tomar decisões científicas.

Uma das limitações do tipo de pesquisa bibliográfica é a apresentação de "dados coletados ou processados de forma equivocada" (Gil, 2007, p. 50). Ou seja, trabalhos que se sustentam em fontes ruins, tendem a reproduzir e ampliar os mesmos erros. Para mitigar essa possibilidade é interessante investigar os autores, as condições em que os dados foram coletados, as referências desses autores e emparelhar diversas fontes sobre o mesmo assunto (GIL, 2007).

Gil (2007), também, define algumas das limitações ao conduzir entrevistas. O autor lista a falta de motivação do entrevistado em responder, a inadequada compreensão das perguntas, fornecimento de afirmações falsas, alguma incapacidade do entrevistado em responder por dificuldade de vocabulário ou 
problemas psicológicos, a influência pessoal que o entrevistador pode exercer sobre o entrevistado, influências de opiniões pessoais do entrevistador e os custos com a aplicação das entrevistas. Mas, ele ressalta que como a flexibilidade é uma característica das entrevistas, tais limitações podem ser contornadas. Por isso, o entrevistador deve estar bem treinado, já que, o sucesso desse tipo de coleta de dados deve-se principalmente a seu desempenho.

Por fim, Flick (2009), revela a principal limitação de uma análise de conteúdo. Por ter uma categorização própria, pode comprometer a visão dos conteúdos, que impede um alcance mais profundo, devido, muitas vezes, à falta de neutralidade do pesquisador. 


\section{Apresentação e análise dos resultados}

Esse capítulo apresenta e analisa os resultados mais relevantes da pesquisa de campo, confrontados com o referencial teórico. Está organizado em quatro seções. A primeira diz respeito ao hábito de ouvir música, a segunda sobre formas com que os entrevistados disseram consumi-la, a terceira procura entender o que os respondentes acham de remunerar artistas e gravadoras e a quarta são críticas aos formatos não mencionados anteriormente.

\subsection{Hábito de consumo}

A tabela 3 apresenta as expressões-chave utilizadas pelos respondentes da geração $X$ (à esquerda) e da $Y$ (à direita), em relação à frequência com que os entrevistados ouvem música. Percebe-se, que nessa categoria, não há grandes diferenças entre gerações. O uso costumeiro é bem evidenciado por todos os que concederam as entrevistas.

\begin{tabular}{|c|c|}
\hline Geração X & Geração $\mathbf{Y}$ \\
\hline "O tempo todo!" & "Bastante" \\
"O dia inteiro" & "Quase todos os dias" \\
"Todos os dias" & "Sempre" \\
"Pelo menos uma vez por dia" & "Todo dia" \\
"Quase todos os dias" & "Diariamente" \\
"Umas quatro vezes por semana" & "O dia todo" \\
\hline
\end{tabular}

Fonte: Autoria própria

\section{Tabela 3 - Expressões-chave sobre consumo dos entrevistados}

Além disso, as nuvens de palavras (figura 4) indicam que o consumo da geração $Y$ é mais diversificado em termos de ocasiões em que se ouve música do que a $X$. Enquanto essa utiliza mais em casa, carro e no trabalho, aquela vai além dos utilizados pela $X$ - consome também na faculdade e na academia. 

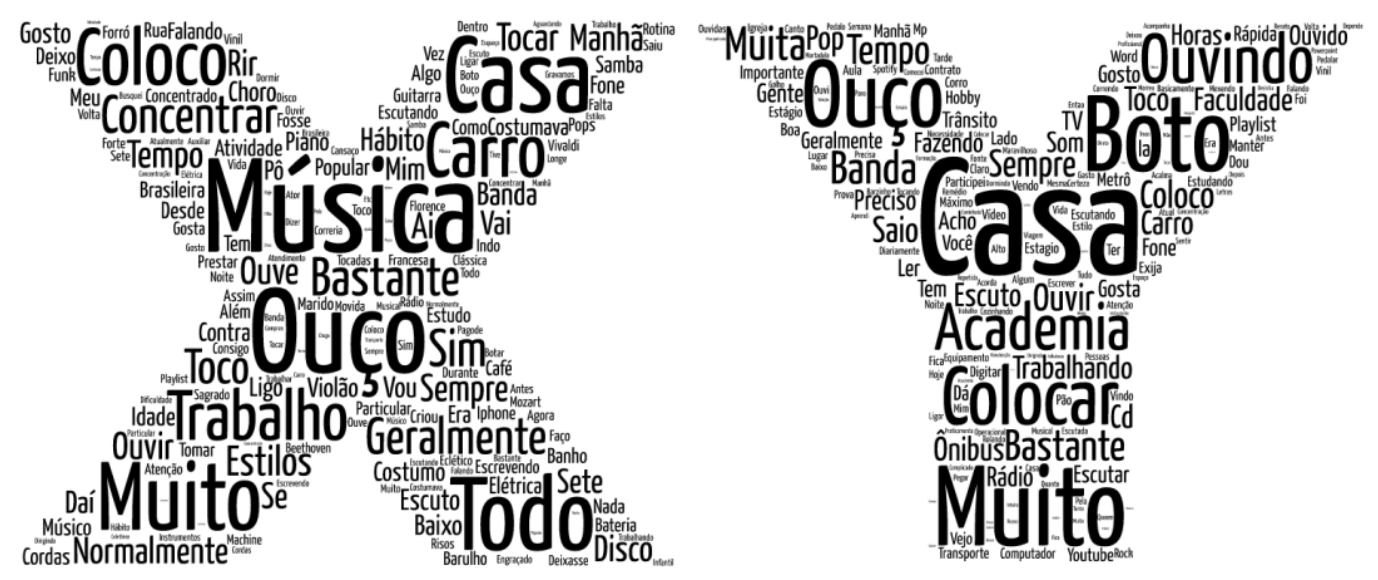

Fonte: Autoria própria com auxílio do site Tagul.com

Figura 4 - Nuvens de palavras: hábito de consumo de música

Com relação à geração $\mathrm{X}$, mesmo os que afirmaram ter diminuído o consumo, principalmente por não possuir tempo disponível, demonstraram uma alta frequência.

Costumava, bastante. Costumava dizer que era movida à música, mas hoje ouço bem menos, por falta de tempo ou cansaço. Ouço em casa, no transporte, na rua, enquanto faço compras, enquanto estou aguardando algum atendimento, etc. (X4)

Interessante notar que algumas pessoas possuem uma relação tão forte com a música que ela se apresenta como algo importante na rotina e na vida delas - como ter mais concentração no trabalho.

Eu escuto o dia inteiro no trabalho. Eu tenho dificuldade de concentração e então a música me ajuda a me concentrar do que tá em volta. (X7)

Além disso, uma das respondentes indicou uma relação forte com a forma como escuta música. Ela possui um iPhone e a única forma de adquirir músicas é por meio do iTunes, aplicativo desenvolvido pela mesma empresa do smartphone preferido dela, a Apple. Essa situação corrobora com o que Solomon (2011) descreve como sendo eu estendo no nível individual, no qual a pessoa considera um objeto como se fosse parte dela. Com relação ao envolvimento, tal atitude estaria mais posicionada para o lado da paixão do que 
inércia, corroborando até com o conceito de cult, em que a pessoa possui lealdade incondicional pela marca.

Sim, ouço todo dia. Eu ouço de manhã, normalmente quando vou tomar banho, eu ligo o iPhone e deixo tocar. Às vezes até no trabalho quando eu preciso me concentrar pra fazer algum tipo de relatório e tá barulho (X2)

O conceito de envolvimento também se aplica a um dos entrevistados que diz ter a necessidade de ouvir pelo menos um disco de vinil por dia. Nesse caso teria um envolvimento emocional porque ele diz ser algo importante na via dele, inclusive para estar na rotina de uma maneira tão presente.

Pô, bastante. Pelo menos uma vez por dia. Normalmente, pela correria do dia a dia, é à noite. Eu tento ouvir pelo menos um disco (de vinil) antes do dormir, tipo isso. É um hábito, hábito mesmo... A música tá na minha vida também. Bastante forte. (X6)

Os entrevistados da geração $Y$ não se expressaram de forma muito diferente da $X$. Inclusive, a música também foi relacionada como algo que acalma, que faz parte da rotina. A ideia de individualização no ato de ouvir música que começou a existir desde 1979 com o walkman (BORGES, 2011), continua uma tendência neste grupo de entrevistados. Inclusive, alguns respondentes evidenciaram o uso de fones de ouvido nas suas rotinas.

Claro. Bastante. Todo dia eu escuto música. Eu sou do tipo que já gosta de ouvir quando acorda já gosta de colocar um som. E quando eu vou pedalar, pedalo bastante, coloco um som. Acho que todo tempo que eu puder, eu vou colocar. Se eu tiver em casa, se eu tiver no transporte, boto um fone de ouvido. Então é tipo, sempre que posso. (Y4)

Sim. Todo dia. Ouço música de manhã, praticamente a manhã inteira eu ouço música. Além disso, ouço música quando estou no metrô, tarde e noite. Só paro de ouvir música quando tenho aula ou estou estudando em casa pra uma prova... A música é importante pra mim porque ela me acalma, é como um remédio que relaxa. (Y5) 
O dia todo [...]. Por exemplo, acordo, boto fone de ouvido enquanto não chego da faculdade. Na volta a mesma coisa. (Y6)

\subsection{Forma de ouvir}

As nuvens de palavras na figura 5 , deixam claro que as mídias físicas estão mais presentes na geração $X$, enquanto que a $Y$ apresenta uma inclinação maior para as mídias digitais, principalmente os streamings. Enquanto na $X$, apenas o Spotify foi mencionado, na $Y$, verifica-se que além desse, o Youtube e o Rdio também foram lembrados. Até mesmo os tamanhos das palavras nas nuvens corroboram com essa análise.
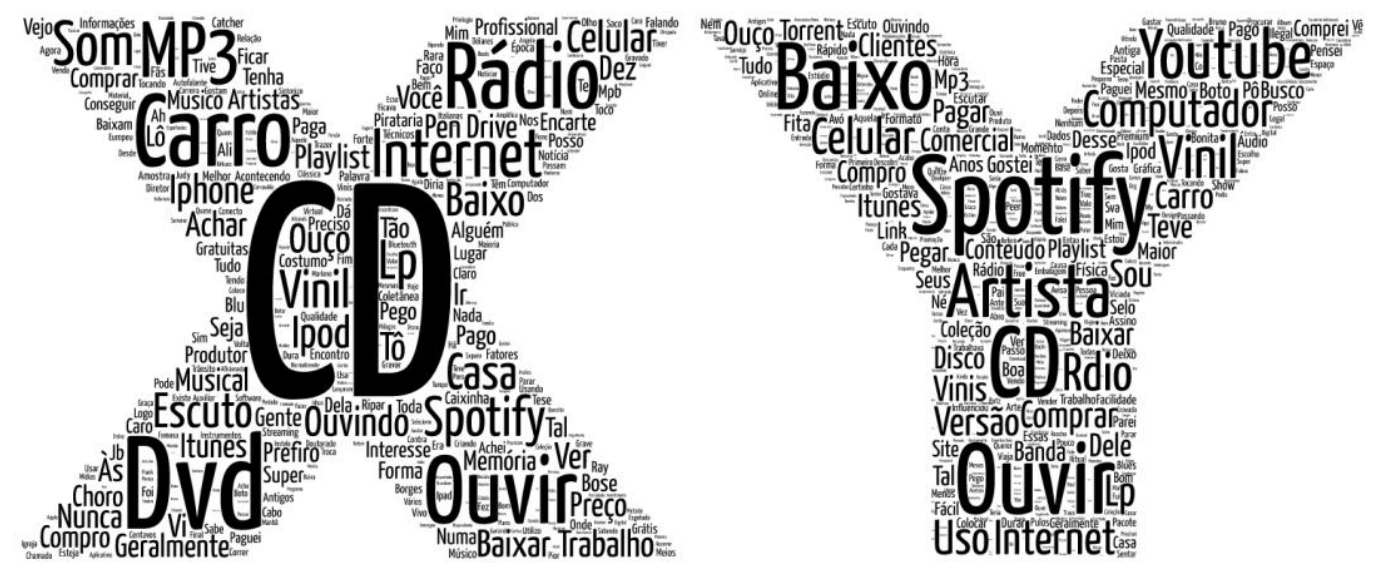

Fonte: Autoria própria com auxílio do site Tagul.com

Figura 5 - Nuvem de palavras: formas de ouvir música

Os entrevistados acima dos quarenta anos, que são os mais velhos da geração $X$, utilizam, de forma mais confortável, os meios físicos, porém, também consomem meios digitais, principalmente com auxílio de filhos ou amigos. Isso corrobora com a pesquisa realizada por Martins (2012), que diz que pessoas por volta dos quarenta e quatro anos são menos propensas a utilizar meios digitais por desconhecimento ou falta de tempo para aprender e compram mídias físicas. Entretanto, já utilizam internet com mais frequência.

Uma entrevistada revelou que uma amiga de trabalho a ensinou o meio com que mais consome música nos dias de hoje. De acordo com Solomon (2011), seria uma influência direta (grupo de afinidade) por grupo de referência. Outra entrevistada indicou dificuldade e falta de tempo para buscar música. 
Assim, suas filhas a ajudam nessa tarefa, uma influência familiar no consumo. Ou seja, as influências mais presentes nesse Coorte são de fatores sociais.

Eu escuto no rádio. Às vezes $C D$. Eu tenho também aquele pen drive, né? Costumo baixar da internet e escutar através do pen drive... Eu uso o Catcher (programa aTube Catcher, em que a pessoa instala no computador para baixar de graça). Uma amiga do meu trabalho que me ensinou, só sei baixar dessa forma. (X5)

Além do rádio ou $C D$, eu escuto também as músicas que eu tenho gravada no iPod... Músicas que eu baixo da internet... Geralmente eu tenho delegado essa função para as minhas filhas (uma de 10 e outra de 12 anos), tipo 'baixa ai pra mamãe não sei quantas músicas do Lô Borges ou Frank Sinatra', ai elas baixam. (X8)

Já os entrevistados mais novos dentro da geração $X$ (que ainda não chegaram aos quarenta anos) possuem um conhecimento da tecnologia, tendem a pagar por música porque compreendem a necessidade de remunerar o artista e acham mais fácil para adquirir e utilizar. As transcrições abaixo confirmam a pesquisa de Martins (2012). O autor concluiu que essas pessoas compram mais online, percebem a necessidade de remunerar e não querem se aprofundar em conhecimentos de informática, logo, pagam. Essa questão da remuneração será aprofundada na próxima categoria, de direitos autorais. Mas as duas próximas citações são de pessoas que apreciam remunerar artistas e gravadoras.

Normalmente eu compro pelo iPhone, pelo iTunes [...] Tipo 99,9\% vem do iTunes. É mais prático. Você paga tipo 99 centavos de dólares e tem a música ali [...] Eu não preciso comprar um $C D$ todo, posso comprar só a música [...] E tem o Spotify, que você pode criar as playlists e usar por ali. Confesso que ainda não entrei pra mexer, pra ver como funciona. Então prefiro pagar... Acaba sendo mais prático... Eu uso aquele Shazam, aquele aplicativo, que se tiver tocando uma música que eu gostei e não sei qual é, ai eu aplico no Shazam e ele me diz qual é a música que ta tocando. Por ali mesmo ele me indexa pra comprar a música pelo iTunes. Então é muito mais prático. Eu já tenho a música que eu quero na minha playlist, entendeu? 
É praticidade! [...] Eu fiz uma vez (referindo-se a download ilegal), mas foi pra filmes. Daí enchi meu computador de vírus. Ai nunca mais fiz download assim. (X2)

A entrevistada acima disse preferir o iTunes porque não precisa mais comprar o álbum inteiro, pode consumir apenas as músicas separadas que quiser. Isso corrobora com a citação da cantora americana Beyoncé que disse que as pessoas não se preocupam mais com a obra completa e sim com os principais singles (Elgerse \& Smith, 2014).

Geralmente eu ouço no trabalho, com um fone de ouvido pelo Spotify versão paga [...]. Teve uma época que eu baixava música e colocava no celular. Só que hoje, a memória do celular a gente usa muito mais pra foto e outras coisas. Eu, pelo menos, não tenho mais memória no celular pra botar playlist de música. Então, o fato de pagar me ajuda a ter isso na nuvem, de forma que eu não preciso mais gastar memória do meu celular pra isso [...]. Considero o preço justo, um CD, um DVD é mais caro do que isso. Além disso, posso ouvir qualquer estilo, qualquer música, em qualquer lugar, eu tenho playlists pro meu filho, por esse valor. Outra coisa que me agrada muito no Spotify é ele entender o meu gosto musical e me sugerir músicas. Então, eu não tenho muito trabalho de escolher. (X7)

Este depoimento está de acordo com que Genes, Craveiro \& Proença (2012) disseram sobre os streamings. Os autores afirmaram que as pessoas não querem possuir uma versão digital caso consigam ouvir instantaneamente, sem a necessidade de baixar, sem ocupar memória.

Há pessoas que disseram comprar $C D$, mas também, consomem downloads ilegais. E o principal motivo de utilizar a segunda maneira é não encontrar CDs de alguns artistas que gostariam de ter. Mesmo tendo de forma grátis, um dos entrevistados disse que gosta de comprar para ter o encarte e estudar os detalhes que compõem esse material gráfico. Além de ter uma relação pessoal com a música, já que se diz músico profissional. Essa necessidade de entender todos os componentes enquadra-se no que Solomon (2011) chama de envolvimento cognitivo, afinal, sente-se a necessidade de aprender todas as especificações do produto. 
Outra entrevistada disse que compra todos os CDs da Madonna, para manter a coleção de vinte e nove anos, e os da Ângela Maria e Cauby Peixoto, para mostrar para os produtores que ainda há público para esses artistas. Ela afirma que há preços abusivos para determinados CDs e que utiliza comunidade de fãs para trocas de MP3. Nesse caso, de acordo com Solomon (2011) haveria um envolvimento emocional porque ela possui uma coleção e ao mesmo tempo quer divulgar, provar que determinados artistas ainda possuem público. Isso indica o afeto que ela possui por seus artistas favoritos.

Eu prefiro ter um $C D$ porque o $C D$ vem além da música, tem um encarte [...]. Eu gosto de ter um encarte, eu gosto de saber quem está tocando, o produtor musical, onde foi gravado, que instrumentos as pessoas estão usando [...]. Eu utilizo meios não pagos também. Tem músicas que são difíceis de você conseguir [...] $C D$ esgotado, gente que tem o vinil e não tem $C D$ e passa pra MP3 [...]. Então tem música, tem gravação que é super rara. Se eu não conseguir $C D$ que tenha, eu pego, baixo de alguém que tenha. (X1)

Eu não tenho nada contra $C D$, inclusive tenho vários, mas ficava muito chateada porque não encontrava $C D s$ dos artistas que mais gosto, os mais antigos. [...] Então fui obrigada a recorrer à Internet. Se não fosse por isso, não conheceria metade da obra desses artistas. Então, no fim, acabo ouvindo mais os MP3 que baixo (ilegalmente). [...] Faço questão de comprar todos os CDs da Madonna (pra não estragar a coleção, que já dura 29 anos), do Cauby, da Angela (porque os produtores precisam ver que há público pra eles sim), e tudo o mais que eu encontrar desses artistas que não seja mais uma coletânea. Judy Garland então é impossível; só comprando importado, o que é super caro, ou baixando da internet mesmo. Só que, pela praticidade do MP3, eu acabo ripando os CDs e pondo as músicas no celular. (X4)

Uma das entrevistadas revelou que prefere o que é mais fácil. E, para ela, o mais fácil é escutar rádio ou Spotify (versão grátis). Inclusive, por admitir não ser "tão aficionada", indica que ela estaria mais em um estado de inércia do que paixão, de acordo com Solomon (2011). Afinal, ela está com uma menor motivação para busca de outras alternativas, prefere o que é mais fácil. 
Quando eu tô em casa eu uso rádio ou eu uso Spotify, que é o aplicativo de música... No carro é sempre o rádio mesmo... E no trabalho eu escuto geralmente rádio que tem no virtual, sabe? [...] Eu acho que eu não sou uma pessoa tão aficionada assim. As pessoas que eu vejo que gostam... Elas baixam, levam iPad, iPod, não sei o que... Eu acho que dá muito trabalho. Gosto de ouvir o que está mais facilmente assim. (X3)

O autor Martins (2012) concluiu seu estudo dizendo que os jovens da faixa etária que corresponde a geração $Y$ abandonaram o hábito de comprar mídias físicas devido à facilidade de se obter as digitais. Entretanto, as entrevistas desde estudo evidenciam que ainda há Millenials interessados em mídias físicas, apesar de ser bem verdade que as mídias digitais dominam entre os respondentes.

Hoje em dia eu só ouço no Youtube ou Spotify. Eu não baixo mais nada. Meu iPod tá completamente engavetado. (Y2)

Spotify, boa parte das vezes. Quando eu descubro um artista que eu gosto mesmo, eu baixo. llegal (risos). Boto no meu celular pra não gastar meus dados e não ficar travando o tempo todo o celular, porque as vezes a conexão trava, boto no ouvido e vou. (Y3)

Eu ouço no celular pelo Spotify Premium, eu compro $C D$, eu compro vinil [...] E às vezes eu compro pelo iTunes [...] Porque quando eu gosto de alguma música pelo Spotify, eu gosto de comprar a versão física (CD). E, se eu gosto da versão física, eu compro o vinil. (Y8)

Martins (2012) constatou em sua pesquisa, que pessoas nessa geração não acham ilegal baixar sem pagar. Houve entrevistados que evidenciaram isso nos fragmentos abaixo.

Sou de uma geração que a gente tem a internet pra ser de graça. Aí eu não me adaptei ao Spotify. Fiquei usando bastante uma época o MixClound e o SoundCloud, que tem música online de graça, não tem propaganda... E acabei voltando a lógica que eu tinha, no início da internet, que é de baixar música. (Y4) 
Música é lazer. Não deveria ser pago assim (risos). (Y1)

A marca Spotify é adorada pelos entrevistados que usam serviço de streaming, inclusive, muitas vezes sendo a única lembrada no segmento. Isso revela um envolvimento de teor cult, conforme Solomon (2011) descreve pessoas que possuem lealdade incondicional.

Spotify. Sim, amo, uso, recomendo. Já fiz com que muitas pessoas fossem pro Spotify e pagassem. Sou super disseminadora. Eu fui uma das usuárias beta... O Spotify existe há pouco tempo no Brasil. Só que eu descobri o Spotify em 2011 quando eu fui pro meu intercambio em Londres. Descobri lá, só que aqui eu não tinha acesso. Mas quando o Spotify descobre sua localidade, ele informa que você não tem acesso mas pede pra cadastrar porque assim que chegar no seu local, eles vão te informar. Então como eu fiz esse cadastro há muito tempo atrás, eu fui informada que estava chegando no Brasil e eu fui usuária beta. Eu fui uma das primeiras pessoas a ter o Spotify. A exclusiva (risos). (Y1)

Só conheço Spotify. Nem sei se tem outro. Eu sei o de vídeo, que era o Popcorn Time, que eu amava. Agora acabou, não tem mais. (Y2)

Um entrevistado, que também fã do Spotify, possui um olhar mais crítico com relação aos streamings porque ele já utilizou três marcas diferentes. Com essa experiência ele disse preferir o Spotify pela interface e facilidade de uso.

Tem o Spotify, tem o Apple Music, tem o Tidal. Eu já usei esses três. Mas eu gosto do Spotify... O que eu percebo é uma preferência da pessoa pela interface do aplicativo, sabe? E pelo quanto vai pagar. O Tidal não tem versão de graça, o Apple Music só tem três meses, o Spotify tem a versão grátis que escuta propaganda. Gosto da interface do aplicativo, acho fácil de usar, acho fácil de pesquisar o que eu quero, de ter música off-line, criar minhas playlists de forma fácil. Acho que vai muito da interface. Já eu, não gostei muito do Apple Music, apesar de ser um apple fanboy, não gostei do Apple Music. (Y8) 
Esse entrevistado utiliza diversas formas para ouvir música. Para ele, a embalagem é um item valorizado, inclusive, é um dos motivos de ter aderido ao vinil. E não são LPs antigos, de colecionadores, são de artistas que lançam atualmente. De acordo com Gomes, Azevedo \& Peçanha (2014), o apelo nostálgico está de volta porque a tecnologia tem tornado os produtos muito similares. E os produtos antigos remetem uma ideia de originalidade. Assim, vai além das necessidades utilitárias, satisfaz as hedônicas também. Isso é facilmente verificado ao perceber que a indústria tem lançado LPs de artistas contemporâneos, ou seja, utilizam a tecnologia vigente com o formato retrô.

Outro ponto interessante é que havia artistas, como Taylor Swift, que não colocaram seus álbuns na plataforma streaming pela má remuneração. Verificase que há pessoas dispostas a irem em outras fontes pagas para adquirir essas músicas, como no iTunes.

Quando tem uma versão especial, tipo a Rihanna que teve agora, o último $C D$ dela, teve uma versão super especial. Eu comprei pra ter ele pra mim... Ele tinha uma embalagem especial, um conteúdo diferente, o pacote, a embalagem. Eles chamam de versão deluxe [...]. Eu comprava uns dois CDs por mês. Hoje só compro quando a embalagem e o design é legal [...]. Eu comprei meu primeiro vinil em 2013. E eu comprei porque era uma versão especial da banda The Killers, ele era vermelho, bem bonito... Só compro vinis atuais, não compro aqueles antigos, de colecionadores. [...] O iTunes geralmente é quando não tem no Spotify, tipo Adele e Taylor Swift. Aí eu compro no iTunes... Mesmo assim, tem uma forma de exportar as músicas que você tem pro Spotify. Digo, músicas próprias. (Y8)

Verifica-se que a influência que predomina na geração $Y$ é de fator pessoal, pelo próprio estilo de vida dos entrevistados. Essa é uma geração conectada, como o autor Solomon (2011) definiu. Assim, o hábito de ir procurar informações e novas formas de ouvir música torna a influência no processo de compra diferente da $\mathrm{X}$. Conforme analisado no início dessa categoria, as influências da geração $X$ são relacionadas à fatores sociais, por meio de grupos de referência e familiar. 
Outro ponto interessante é que um dos objetivos intermediários foi evidenciado pela entrevistada X2 no início desse bloco - a questão da valorização dos singles contra o apreço pelo álbum inteiro. Entre os entrevistados verificou-se que que as pessoas que costumam consumir apenas mídias digitais, tendem a ouvir apenas músicas isoladas, enquanto que os mais adeptos de mídias físicas valorizam o álbum por inteiro. Nos fragmentos abaixo, por exemplo, verifica-se a entrevistada $Y 2$, que possui streaming como formato preferido e o entrevistado $\mathrm{Y} 6$ que prefere vinil.

Aí você ficava 'ah, comprei um $C D$ inteiro pra ouvir três músicas?!' (Y2)

É muito importante ouvir um disco inteiro. É uma das partes do vinil que ganha e tem um apelo muito maior.. [...] $O$ single é o que o artista acha que vai vender mais, mas não significa que é a melhor música... A gente ta na geração da pressa. As pessoas colocam playlists com músicas de vários cantores. (Y6)

\subsection{Direitos autorais}

Essa categoria procura compreender os motivos pelos quais os entrevistados pagam ou não para consumir música, incluindo, os que em algumas ocasiões pagam e em outras não. Por esse motivo, essa categoria está desmembrada em três - apenas utilizam mídias pagas, apenas utilizam mídias não pagas e utilizam mídias pagas e não pagas. Inclusive, as nuvens de palavras presentes na figura 6 não induziram uma análise que discrimine essa categoria em gerações. Afinal, conforme será visto, as opiniões sobre as perguntas desse bloco foram similares entre ambos os perfis. 

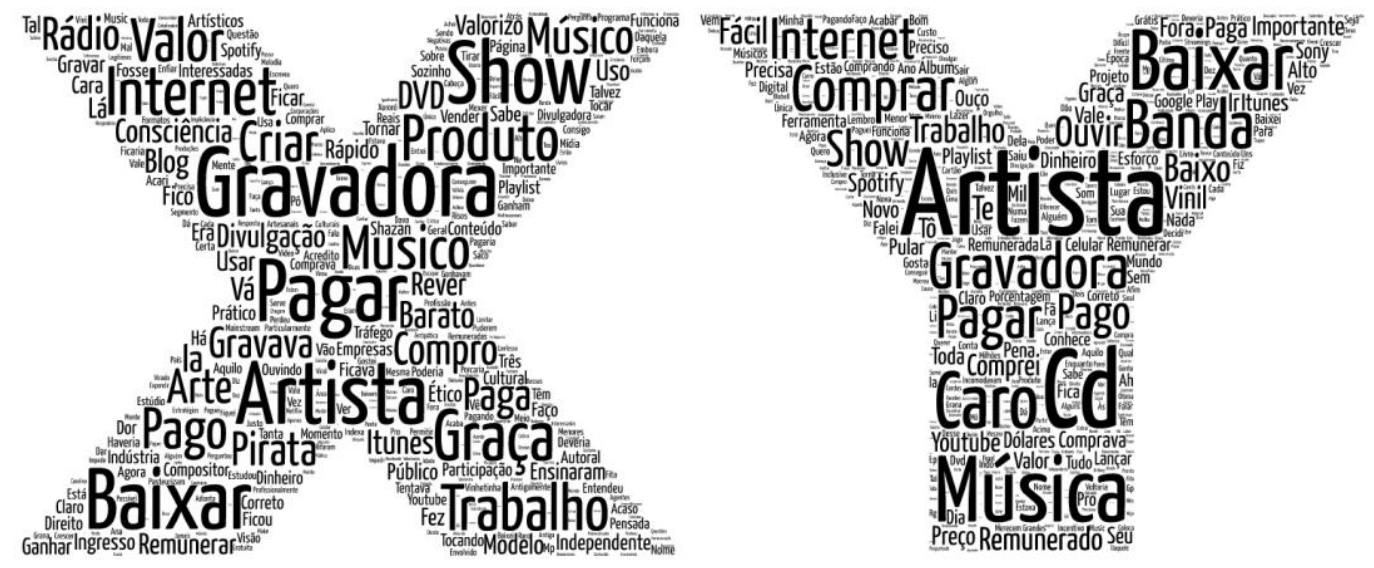

Fonte: Autoria própria com auxílio do site Tagul.com

Figura 6 - Nuvens de palavras: direitos autorais

\subsubsection{Apenas utilizam mídias pagas}

Os entrevistados, de ambas as gerações, que utilizam apenas meios pagos indicaram que são totalmente a favor de remunerar artistas. Entretanto, a geração $Y$ possui uma imagem ruim das gravadoras. Essa má impressão será verificada também nos outros dois blocos. Ao que tudo indica, os consumidores que possuem essa imagem concordam com a ideia de oligopólio formado pelas principais gravadoras atualmente (Sony BMG, EMI, Universal e Warner), como foi evidenciado pelos autores Kretzer \& Toyama (2008). Além disso, o motivo de apenas utilizar mídias pagas na geração $X$ é por facilidade de uso e na $Y$ por achar ser o mais correto.

Então prefiro pagar. Acaba sendo mais prático. Eu acho correto pagar. Tem que ter o direito autoral. $O$ artista que escreveu uma música, perdeu tempo escrevendo. Então acho justo cobrar [...]. Com relação a gravadora é como quando se faz um blog na internet. O blog você pode criar de forma gratuita, mas não adianta criar um blog se você não tiver tráfego, pessoas que entram na sua página. Você precisa pagar alguém, pagar hospedagem para ter tráfego na sua página. Eu acho que assim, o artista pode divulgar e vender sua música sozinho. O Youtube hoje em dia é um potencializador/catalizador para poder expandir isso o mais rápido possível. Você se tornar um viral, mas pode não tornar. Então eu acho que o papel da gravadora ali é um pouco do papel de um hospedeiro [...]. Vai divulgar a 
música do artista. Nada impede que ele faça sozinho [...]. Mas, acho que é uma forma de crescer mais rápido, de ficar conhecido mais rápido. (X2)

Eu não gostaria de trabalhar e não receber por isso. Você paga por aquilo. Se você vai num teatro, você paga pra valorizar o trabalho do ator. Se você é um administrador, você vai querer receber por um plano de negócios que vai fazer... Sempre pensei assim [...]. As grandes gravadoras, por exemplo, uma cantora brasileira famosa (ele conhece uma pessoa que trabalha em uma grande gravadora) [...]. Todos os contratos que ela faz com a gravadora, a música vira da gravadora e não dela. Apesar dela ter cantado, ter escrito, a música não é dela, é da gravadora. Eu não acho isso certo. E todo trabalho que ela tiver, uma porcentagem alta é da gravadora [...]. Hoje em dia, não é uma coisa tão importante quanto era antigamente. Agora qualquer pessoa pode fazer $O C D$ em casa, lançar no Soundcloud ou no Spotify e ser independente. Muito mais fácil. Não necessariamente você precisa da gravadora pra crescer. (Y8)

Apesar de Kretzer \& Toyama (2008) falarem que a tecnologia auxilia gravadoras pequenas a terem uma liberdade maior com relação as grandes, pode-se fazer um paralelo com os artistas se libertarem de qualquer gravadora. A X2 indicou uma possibilidade de torna-se viral no Youtube, enquanto o Y8 indicou lançamentos independentes em outras plataformas de streaming, como Soundclound e Spotify.

\subsubsection{Apenas utilizam mídias não pagas}

A entrevistada X3 já havia revelado que não paga por música por não se sentir tão "aficcionada" como outras pessoas que ela conhece. Assim, ela ouve por meio de rádio do carro, rádio online no trabalho e Spotify versão grátis. Ela revelou que até já pagou o Spotify por alguns meses, mas não continuou por não ver tanto valor em pagar, já que, o rádio e a versão grátis já a satisfaz. Ela não chega a recorrer aos downloads ilegais justamente por não achar prático. Verifica-se que o conceito de inércia de Solomon (2011) está ligado a não pagar por música pela geração $X$. 
Ao mesmo tempo, ela e outros entrevistados relacionaram baixar ilegalmente como uma forma de divulgação e não de distribuição. Para eles, isso facilita o conhecimento das pessoas sobre o trabalho de determinado artista e resulta em ingressos de shows. Ainda com relação a X3, ela fez um paralelo histórico por informar que sempre houve pirataria, desde as fitas K7. Inclusive, o autor Borges (2011) já havia dito que essa mídia iniciou o processo de reprodução caseira.

Eu não pago pra baixar música. Teria que rever um pouco esse modelo, que o artista tem inclusive, eu acho que é uma forma de divulgação... Quando você ta ouvindo uma música que você baixa, você também ta participando daquela divulgação, talvez você vá num show [...] Isso sempre foi assim [...] Então eu já era uma pirata antigamente porque você gravava a música do rádio. A única coisa é que você tentava escapar da vinhetinha da rádio. Então você gravava e tentava fugir daquela vinhetinha. Você gravava numa fita $K 7$, dava trabalho porque você não sabia como ia ficar e depois ficava ouvindo. Se fosse pirata, era pirata igualmente porque eu também não estava pagando nenhum direito autoral.. (X3)

Da mesma forma que geração $X$, a $Y$ acredita que download ilegal pode aumentar a visibilidade do artista e servir como fonte para ser remunerado por shows. Um entrevistado indicou que artistas independentes utilizam a internet para disponibilizar conteúdo grátis e assim gerar plateia para shows. Isso corrobora com que Kretzer \& Toyama (2008) disse do avanço da tecnologia para libertar pequenas gravadoras independentes das grandes e assim conseguir lançar seus produtos. Até mesmo a entrevistada Y3, que não compra música de artistas grandes, se disse interessada em ir aos shows.

O meu comportamento na internet foi de buscar soluções gratuitas. Mas eu acho que é mais a cultura de querer uma alternativa gratuita na internet. Sou de uma época que vi a internet crescendo e trazendo coisas mais fáceis, tipo, sempre baixei joguinhos, sem pagar. Aí, eu vejo a internet como uma forma de conseguir conteúdo grátis. [...] Shows, eu acho que assim, você lançar o conteúdo grátis, como faz o Criolo e outras bandas independentes, é uma ótima ferramenta de divulgar o seu trabalho. [...] Difícil você fazer alguém ir no seu show se a 
pessoa não conhece seu som sabe? Acho que é uma ótima ferramenta de oferecer o álbum de graça ou até oferecer pra download se as pessoas quiserem. É uma forma de se promover. (Y4)

Eu baixo o artista que já é podre de rico e que pra ele já não vai fazer diferença [...] quando você está disponibilizado por outras pessoas na internet, de graça, ilegalmente você alcança um público muito maior [...] A remuneração é indireta. Você atinge um número muito maior através dos downloads ilegais. Dessa maneira, o público te conhece mais. 'Ah, como é que ele vai ser remunerado?' Eu vou num show dele. Você da dinheiro pra ele dessa maneira... Isso eu faço. Eu não fui no show do Maroon 5. Eu gostaria de ter ido mas não fui. Mas baixo o trabalho deles livremente. O cara mora lá em Berveley Hills, tem trezendos mil carros, Porche. Não daria dinheiro pra ele de outra forma, mas iria num show dele. (Y3)

Interessante que no bloco anterior, uma entrevistada da geração $X$ disse que pagava por achar mais fácil. Entretanto, esse bloco revelou que a geração $Y$ acha mais fácil baixar do que comprar, devido ao processo burocrático de compra. Isso pode se categorizar no que Solomon (2011) chama de "digitais de nascença", já que essa geração utiliza demasiadamente a internet, há uma facilidade maior do que a geração $X$, que acha melhor pagar do que infectar o computador com vírus.

Geralmente quando comprava eu tinha um esforço maior... Ou eu ia no lugar e comprava o CD/DVD, ou, quando comprava pela internet eu precisava digitar CPF, RG, cartão de crédito, nome do cão, quando ocorreu a segunda guerra mundial... Aí eu desanimava. Por isso, acho mais fácil baixar. É de graça e o esforço é menor. (Y5)

\subsubsection{Utilizam mídias pagas e não pagas}

Os entrevistados, que às vezes pagam e às vezes não pagam para consumir música, afirmaram que isso acontece por dois motivos complementares: preços abusivos de determinadas mídias e pouco dinheiro para consumi-las. Suscita-se o conceito de renda discricionária, em que Churchil 
(2013) define como sendo o dinheiro que sobra para gastos com produtos e serviços que sobram depois de pagar despesas essenciais. Ao mesmo tempo, esses consumidores acham importante pagar por música. $E$ os fragmentos abaixo indicam que isso é independente de geração.

Porque eu já pago tanta coisa (ao ser perguntada porque não costuma pagar por música). Ai eu fico assim sabe? A gente ta vivendo um momento em que tem que pagar o mínimo. Já pago tanta coisa que decidi que música eu não vou pagar. Não é uma coisa essencial. Ultimamente, esse ano, eu declarei que eu não ia pagar nada que eu realmente não precisasse. E música foi uma das coisas que eu precisei. [...] Eu valorizo muito um artista. Eu posso até não pagar por música, mas se eu for num show, mesmo que seja de um amigo, eu faço questão de pagar o ingresso. (X8)

Eu acho importante pagar por música porque eu tô financiando um artista. E ainda assim, de relançamento já foi gravado, já foi produzido, já foi financiado e ainda assim, tem esse valor? Qual o custo que a gravadora teve em relançar um álbum por um preço tão alto? Não acho justo. $E$ as coisas novas que lançam, se tornam inviáveis de pagar um vinil de 130 reais e importar ainda esse vinil. Então, baixar se torna mais prático. É mais falta de grana pra poder investir. (YG)

Eu queria comprar uma música da Blubell e tava seis reais. Seis reais em uma única música, eu acho um pouco acima do valor. Você vai comprar na App Store, no iTunes, custa 15 dólares, 60 reais. Acho bem absurdo o valor da música hoje... Acho que o da Blubell foi no Google Play. (Y7)

O entrevistado da última citação acha que a divulgação que leva o consumidor ao show pode ser tão importante que pode o induzir a compra de mídia física em um dos concertos. De acordo com Solomon (2011) seria um envolvimento emocional que ocorreu durante a vivencia daquele serviço que motivou a compra dos CDs a venda no mesmo ambiente. Esse mesmo entrevistado apoia o fim das gravadora motivado pelo avanço tecnológico. Inclusive, com esse pensamento ele acredita que a distribuição do conteúdo seja 
direta, do artista para o cliente, assim como o nível zero dos canais de marketing promovido por Kotler \& Keller (2012).

Dá certo, minha esposa, por exemplo, é fã de um cantor, que eu nem lembro o nome, não conheço direito. Toda vez que ela vai no show dele, ela compra o CD autografado. Ela deve ter dez $C D s$, todos repetidos. Muitos CDs que eu compro foram em shows. Você ta tão empolgado com aquele momento que o cara te proporcionou que você compra toalha se te venderem. (Y7)

Além disso, esse grupo, novamente independente de geração, expressou que possui uma imagem ruim das gravadoras e que a música gratuita resulta em divulgação para shows.

Eu tenho uma visão muito antipática em relação as grandes gravadoras. Mas por exemplo, eu compro muito CD de músicos que praticamente são de produções pequenas, de gravadoras pequenas [...] Não ficaria muito com dor na consciência de baixar um $C D$ da Sony Music [...] Pra mim elas são multinacionais, empresas apenas interessadas em ganhar dinheiro. Quanto mais dinheiro elas puderem tirar do artista ou do público consumidor... Elas vão fazer isso. (X1)

A gravadora serve como uma intermediária. Tem que entender que porcentagem é essa. Se o produto só existe por causa de um artista, não acho justo que a gravadora fique com mais da metade do dinheiro gerado. (Y2)

Não acredito que eles sofram muito com o compartilhamento na Internet, ao contrário, acho que isso divulga o trabalho deles. Por exemplo, eu jamais teria virado fã da Ana Carolina se não fosse pelo YouTube, totalmente por acaso. Isso me fez, por exemplo, pagar uma grana que eu não tinha pra ir a um show dela. É uma excelente ferramenta de divulgação. E não acho que eles saiam prejudicados, pois o valor dos ingressos para os shows, que é altíssimo, deve compensar essa perda. E isso, todo o mundo que pode, paga. Os shows a que vou estão sempre superlotados. $(X 4)$ 


\subsection{Críticas aos formatos não mencionados}

Essa categoria tem por objetivo entender o que os entrevistados acham das mídias descritas na tabela 4. Algumas dessas mídias já foram abordadas nas categorias anteriores, geralmente de modo positivo, por serem as mídias utilizadas pelos respondentes. Entretanto, no fim das entrevistas foram citadas essas formas de ouvir música para entender se os entrevistados tinham conhecimentos sobre elas e, assim, falarem abertamente. Logo, esse tópico terá as opiniões das pessoas que não citaram essas mídias anteriormente.

\begin{tabular}{|cc|}
\hline CD & Canais de áudio na TV \\
DVD & Streamings \\
Blue-Ray & Downloads llegais \\
Vinil & Downloads Pagos \\
Rádio & Ringtones de Celular \\
\hline
\end{tabular}

Fonte: Autoria própria

Tabela 4 - Mídias

\subsubsection{CD}

Os respondentes, da geração $X$, que não utilizam CDs para ouvir música indicaram quatro motivos para o não uso - espaço de armazenamento em casa, necessidade de ter sempre músicas diferentes, o preço ser considerado caro e cada vez menos ter aparelhos que leiam tal mídia.

Já usei, mas não usaria. Primeiro porque é grande, dá muito trabalho... Imagina você, com vários CDs dentro do carro, ficar trocando, ocupando muito espaço. (X2)

Eu dificilmente compro porque eu enjoo muito de música. Tem gente que ouve setenta vezes a mesma música. Eu não! Eu gosto de ouvir várias músicas diferentes... Eu não vou ter uma casa inteira pra comprar um monte de $C D$, até pra estocar tudo isso. Tipo, eu compro CD da Maria Betânia, que eu adoro. (X3)

Seria bom se fosse mais barato... O preço de um CD usado, às vezes vale. Nunca comprei dessa forma, mas já fiquei tentado 
várias vezes. Nas lojas de vinil que eu frequento costuma ter um estoquezinho de CDs usados. (X6)

Não usaria mais. Porque, por exemplo, meu carro já não tem aparelho de CD. Meu carro é novo, 2015, e ele não tem mais a opção de ouvir por aparelho de CD. E em casa, se eu for ouvir, ou é pela NET ou Spotify. (X7)

Com relação à geração $Y$ verificou-se que os entrevistados não querem possuir $C D$, principalmente, porque a tecnologia já substituiu para eles a forma de apreciar música. Lembram de problemas que essa mídia física apresentava e que é um desperdício comprar um CD para ouvir poucas canções, afinal, os singles parecem ser mais importantes do que a obra completa. $\mathrm{E}$, quando compram é para prestigiar algum amigo.

Mas hoje, pra mim, não faz mais sentido ter $C D$ porque, pra que que eu vou querer ter um CD? Eu posso... Ou vai pra nuvem ou vai pro celular ou vai pro meu computador. Eu não preciso ter meios físicos mais. (Y3)

Pra mim já foi época... Quer dizer, ainda é importante. Mas eu acho que a tendência é cada vez mais diminuir. Pelos motivos das mídias digitais estarem crescendo muito... Eu até compro alguns CDs mas assim, eu não uso. Comprei pra dar uma moral pro cara que eu me amarro. (Y5)

Desnecessário. Porque é um formato digital, a arte é pequena. É uma mídia física, mas com qualidade digital. Então, não acho tão útil. Não tem apelo visual, não tem apelo auditivo. Ele perde pro vinil em questão de qualidade e perde pro MP3 em questão de praticidade. (YG)

\subsubsection{DVD}

Com relação a geração $X$, foi apenas nesse momento que a mídia física DVD foi lembrada. Entretanto, foi elogiada e bem aceita.

Eu gosto mais do DVD, que eu vejo a pessoa, sinto como se estivesse num show e no conforto da minha casa. Eu não estou tão perto, mas tô lá vendo a pessoa. As pessoas que eu gosto 
muito, tendo a comprar o DVD, $O C D$ eu já não compro mais. Quero ver o show, que ver entrada, saída, como a pessoa faz. Gosto de ouvir todas as músicas... Aprender músicas novas desses artistas, não só as mais conhecidas. (X3)

Adoro ter os DVDs dos artistas que gosto, tanto shows como documentários. (X4)

Comprar o DVD é mais prático. (...) Mas eu ainda prefiro show ao vivo do que DVD. Eu vou com muita frequência nos shows dos artistas que eu gosto. Tipo, Vitor e Léo, Zeca Pagodinho, Fabio Junior, Calcinha Preta... E também tenho o DVD de todos eles. (X5)

Já os entrevistados da geração $Y$ não são nem um pouco adeptos a comprar e assistir DVDs. Os principais argumentos é não terem paciência e preferirem assistir através do Youtube ou ao vivo. Até foi citado que o formato é obsoleto em termos de qualidade de imagem.

Nunca comprei nenhum show. Ganhei uns, mas nunca assisti. Um amigo me deu um da Beyoncé e outro da Shakira. Ta lá em casa guardado porque nunca tive interesse em parar pra ver DVD. (Y1)

Eu não tenho muito saco pra ficar assistindo. (Y7)

Não. Quando eu quero ver um show de algum artista, eu geralmente vejo no Youtube, tem disponível no Youtube. Ou as vezes passa no Multishow ao vivo. Eu não busco muito DVD não. (Y3)

Eu acho interessante apesar do formato estar ficando obsoleto. Talvez eu acharia mais interessante ter esse formato já em um site. Pra poder comprar em um site. Com uma qualidade que eu pudesse escolher. O DVD é limitado em 480p. Enquanto hoje, tem televisões de $4 k$, de $5 k$, de 1080p, que é o normal de um computador hoje. Então o DVD é meio obsoleto. (Y6) 


\subsubsection{Blue-Ray}

Todos os entrevistados, de ambas gerações, não utilizam e não se mostram interessados em utilizar essa mídia, principalmente por nunca terem comprado o aparelho que lê tal mídia.

Não cheguei a usar, não tenho conhecimento. (X8)

Não tenho o aparelho. (Y1)

\subsubsection{Vinil}

$\mathrm{Na}$ geração $X$ verificou-se que algumas pessoas não querem voltar a ouvir LPs porque ocupa muito espaço e de alguns problemas mais técnicos, como sujeira que ocasionava barulho.

Tinha vários até o ano passado. Mas ocupavam muito espaço, troquei os que me interessavam por CDs. (X4)

Já usei há muito tempo atrás. Agora não. Não tenho mais aparelho de vinil não, nem tenho mais os vinis. Não tenho vontade de usar... O vinil, além de ser grande, é ruim de armazenar ele, pra guardar. (X5)

Não tenho aparelho, não compraria e nem sei qual é a qualidade de hoje em dia... Eu conheço a qualidade da época que eu usava e era péssima. Então, não teria. Na época a qualidade era bem ruim, tipo, se o vinil tivesse sujo, fazia barulho. E hoje não tenho interesse. (X7)

Os vinis possuem uma divergência de opiniões. Enquanto alguns não possuem interesse em utilizar essa mídia, outros querem reviver essa experiência. Inclusive, corrobora-se com as definições de nostalgia promovidas por Solomon (2011) e Gomes, Azevedo e Peçanha (2014) que diz respeito a um apelo considerado clássico, da juventude do consumidor.

Vinil é um negócio meio amor assim, ne? Meu marido tem muitos. E por incrível que pareça, a gente não conseguiu se desfazer... A gente deu vários CDs e os vinis acabaram ficando. 
Acho que por ser retrô, ele acaba ficando como queridinho, não é? Então a gente estava até falando esses dias de comprar um aparelho de vinil pra ouvir esses discos... Eu compraria... São bonitos. (X2)

Eu gostava muito. Vou ser sincera... A qualidade dos sons não era a mesma dos CDs, DVDs...Mas aquela experiência do vinil é legal. [...] O vinil é válido pela experiência, da degustação da música. (X8)

O surpreendente é que a geração $Y$ foi mais positiva em relação ao vinil do que a X. Essa "romantização do passado" parece permear as palavras desses entrevistados, talvez por não ter vivenciado nenhuma parte ruim, como a sujeira que ocasiona ruídos. De acordo com os autores, essa nostalgia evidencia a parte boa de uma época, sem levar em conta as peculiaridades ruins, de acordo com os autores Gomes, Azevedo e Peçanha (2014).

Eu não tenho, mas o meu irmão (de 28 anos) comprou e às vezes ele bota em casa e eu gosto, acho interessante. Algo meio vintage, acho legal.[...] O som é diferente e é uma coisa mais antiga. É bacana entender como a música funcionava antigamente. Hoje é tudo tão digitalizado que eu acho bacana ouvi vinil. É diferente. (Y1)

Eu acho muito legal essa volta do vinil. É clássico. Eu não tenho aparelho, mas tô pensando seriamente em adquirir um porque eu tô vendo esse movimento da volta do vinil e achei interessante. E tem muitos discos disponíveis. Acho clássico, acho bacana pra caramba. Quero ter o aparelho e acho maneiro. (Y4)

\subsubsection{Rádio}

Os entrevistados da geração $X$, disseram que quando escutam rádio é mais para notícia do que música. E tem quem não escuta de modo algum por se incomodar com os comerciais. 
Eu escuto muito rádio... Mas curiosamente eu escuto mais notícia no rádio do que música... Em geral... Música no rádio, quando to viajando de carro. (X1)

Ultimamente só as de notícia. Acabou né? Nesse país o rádio acabou.. (X6)

Não gosto. Sempre tem um comercial, sempre toca alguma coisa que eu não gosto de ouvir. Ainda fico pelo Spotify. (X7)

O poder de escolha, promovido por outras mídias, foi lembrado na geração $Y$ como crítica a escutar rádio. Inclusive, o autor Borges (2011) categorizou a livre distribuição de música como algo libertador para os consumidores, posto que antes as pessoas só podiam ouvir o que era imposto pela indústria e com o início da pirataria ocorreram mudanças profundas no setor que resultaram nas diversas formas utilizadas hoje em dia.

Não costumo ouvir em casa, costumo ouvir no carro. Acho que cada vez menos vamos ouvir rádio. Cada vez mais vamos querer escolher o que a gente quer ouvir. Mas acho bacana, não só pela música, mas pela notícia, ouvir futebol. Mas acho que cada vez menos pra música. Porque música a gente cada vez mais vai querer escolher. (Y4)

\subsubsection{Canais de TV}

Ambas as gerações possuem opiniões parecidas com relação aos canais de áudio na televisão. Geralmente é uma forma secundária de ouvir, seja para limpar a casa ou fazer uma festa. Os que não gostam dizem que é pela repetição, má seleção das músicas e categorização de gêneros musicais inadequados.

A classificação genérica é difícil de funcionar pra muita gente. Deve atender bem pra muitas pessoas. Eu e boa parte das pessoas que apreciam música e vai num ritual simbólico de sentar e ouvir não da muita conta dessa forma, sabe? Isso seria bom pra fazer uma faxina na casa... Você não precisa pensar... (X6) 
Eu gosto (pela NET) porque lá eu consigo colocar o estilo de música que eu gosto e consigo deixar tocando sem interrupção... Ouço geralmente quando eu to limpando a casa ou quando chego estressada do trabalho, já ligo, e deixo tocando. (X7)

Não costumo ouvir, a não ser que tenha uma reunião em casa com os amigos. Ai eu boto, não muito alto, não precisa ficar escolhendo música, daí ninguém se distrai com a música. Fora isso, não uso. (Y1)

Sei... Eu utilizo. É um pouco enjoativo. É um canal que eu uso na Oi TV, então é um canal que só tem música, não tem propaganda, não tem nada. Então, é enjoativo porque acaba repetindo muitas músicas e tal... (Y5)

\subsubsection{Streaming}

Sobre os streamings, os entrevistados da geração $X$ informaram desconhecimento (mesmo depois de eu informar alguns de exemplo), preferência por mídias físicas e só utilizar para filmes.

Streaming eu vejo mais de filmes, séries... De música eu não conheço. Eu sei que tem. (X1)

Nunca tentei... Eu uso muito pra filme... Mas nunca tentei pra música. Mas eu imagino que se eu tiver um tempo e aprender a usar é capaz de eu gostar. Eu tentaria. (X2)

Nunca usei. Só vejo de artistas contemporâneos - e desses, eu compro o $C D$, prefiro. Gosto da mídia física. Então não preciso. (X4)

Não conheço (X8)

Somente um entrevistado desta geração, que havia informado ouvir apenas LPs no início da entrevista, mostrou-se conhecer streamings e utilizar formas variadas - como Youtube e Soundcloud. Disse que nunca utilizou Spotify, mas conhece, sem que o nome do aplicativo fosse mencionado na entrevista. 
Eu uso muito Youtube. Soundclound é uma ferramenta muito legal porque uma ferramenta direta. Você vai com o objetivo de ouvir música. Ele é direto ao assunto, não tem propagaiada... Ele te da a música. O player do Soundcloud é muito estável... Pouquíssimas vezes da ruim, quando a conexão ta ruim, ele te avisa claramente que a música não vai fluir. Basicamente isso, você ta lá pra ouvir música sem firula... Em comparação ao vinil, eu ouço o Soundcloud em busca de coisa nova, artistas novos e desconhecidos que divulgam seus trabalhos lá. Um cara que produziu a música sozinho em casa, um DJ que faz um set duma festa... Sei lá. [...] De aplicativo eu só conheço o Spotify. Nunca usei, já vi gente usando... Com ele eu senti o contrário do SondClound, sabe? Muito burocrático, você tem que baixar o negócio, já no SoundClound você clica no link e acabou. (X6)

Entre os entrevistados da geração $\mathrm{Y}$, a maioria sabe usar streamings.

Acho muito bom. A ideia, como funciona. Fez uma revolução no mercado. Mas eu ainda não sou do tipo que quero gastar, procuro solução grátis. Acho legal streaming mas não pagaria pra um serviço, visto que eu consigo contornar por outros caminhos na internet. (Y4)

Há entrevistados da geração $Y$ que indicaram certa desmotivação pelo Spotify pelo serviço de streaming não possuir o conteúdo de alguns artistas que gostam. Isso foi evidenciado até mesmo por quem assina e gosta do serviço, como a entrevistada Y2.

Eu usei o Spotify por um tempo, até paguei por uns cinco meses... Só que, por não ter o que eu gosto de ouvir, acabei deixando ele de lado. Tem muita coisa moderna e tudo, algumas antigas, só que, se você quer achar uma coisa diferente, já não tem tanto. [...] Alguns artistas que eu não achei foram: Twilight e Pink Mice (bandas alemãs), Still Life e Gaslight (inglesas) e Wara (boliviana). São bandas antigas. (Y6)

Tipo, eu gosto muito de reggaeton. Geralmente são músicas de Porto Rico, Venezuela... Tinha umas músicas que eu já conhecia antes, tinha baixado, tem clipe no Youtube e no Spotify eu não 
encontro. Só tem as mais famosas. Quando eu quero ouvir, é no Youtube. Nem assim eu baixo. (Y2)

\subsubsection{Downloads grátis (ilegais)}

Com relação aos downloads ilegais, os respondentes da geração $X$ que não utilizam disseram que é para não infectar o computador com vírus, utilização do Youtube e ser contra a não remuneração de artistas.

Eu fiz uma vez, mas foi pra filmes. Daí enchi meu computador de vírus. Ai nunca mais fiz download assim. (X2)

A menos que seja gratuito, ok pra mim. Agora, se não for gratuito eu não uso. Eu sou contra o PirateBay e outros mecanismos porque não remunera $O$ artista. $O$ artista tem direito a ser remunerado. (X7)

Os que não utilizam na geração $Y$, disseram que algo parecido com que a geração $X$, não utilizam porque os streamings - Spotify e Youtube - resolvem a situação.

Eu já baixei muita música. Mas agora não mais. Na época eu baixava no KazaA, no 4Shared e baixava do Youtube, transformava em MP3. Mas parei. Se eu baixar cada música que eu escuto? Nossa, vou demorar anos. (Y2)

Eu não uso mais o 4Shared. Já usei... Vou direto no Youtube com o site que faz downloads dos áudios. Pra mim é ótimo. (Y5)

\subsubsection{Download pago}

As respostas com relação a pagar por música, como os serviços do iTunes e Google Play, foram similares nas duas gerações. Quem utiliza os streamings acaba não querendo pagar por música separada, já que, pode ter todas com uma única assinatura.

Eu prefiro pagar pelo Spotify que é algo que eu tenho qualquer música em qualquer lugar. Eu não gostaria de ter que comprar música por música. (X7) 
Nunca fiz, não pretendo fazer. Spotify é um custo benefício melhor. Caso contrário, baixaria de graça. Acho caro pagar música separada. (Y1)

Por fim, outro entrevistado da geração $Y$ lembrou uma forma de comprar música estipulando um valor, pelo site. Essa forma de comprar música é interessante porque indica uma compra sem intermediários, compra-se direto do artista, de acordo com o conceito de Kotler (2012) seria um canal zero. E esse tipo de distribuição aparenta ser favorável para os consumidores que possuem imagens negativas com relação às gravadoras e preços caros.

Já paguei algumas vezes pra incentivar algumas bandas de amigos. Só que não tenho costume. Tem uma galera que paga $o$ iTunes, não sou tão apto. Até porque não tenho iPhone... Eu comprei no Brandcamp, que é um site de streaming, que a banda pode disponibilizar download e eles podem colocar um valor fixo ou não, do valor do disco. Se eu não me engano, o Radiohead fez isso em $2008 \mathrm{com}$ o álbum In Rainbows. Ele disponibilizou e deixou aberto o quanto a pessoa queria pagar, podia ser zero reais, ou um milhão, mas ta ai a obra. Não sei se eles usaram esse site, mas se não me engano no site próprio da banda. (Y6)

\subsubsection{Ringtones}

Com relação aos ringtones, no grupo entrevistado, nem a geração $X$ nem a Y gostam. Os principais motivos são: não utilizar toque no celular (deixar no vibrar) e achar ultrapassado. Os que ainda utilizam dizem baixar ilegalmente uma música e direcionar como toque, assim, não pagam nada pelo serviço.

Não. Prefiro os toques básicos [...]. Prefiro o 'trim' mesmo. (X8)

Gente, mas isso é da época do Motorola V3 né? Nunca comprei e hoje em dia muito menos. (Y2) 


\section{Conclusões e recomendações para novos estudos}

Este capítulo resume as principais contribuições produzidas ao tema em estudo.

Esse trabalho pretendeu investigar como os consumidores encaram as diversas mídias disponibilizadas para o consumo de música. O foco do estudo recaiu sobre entender quais as oportunidades do mercado contemporâneo de distribuição de música. Tal questão se mostra importante na medida em que a tecnologia progride, aparecem novos formatos, além de ter questionamentos referentes à remuneração por meio digital.

Para aprofundar a análise, investigou-se a perspectiva de diversos autores, que auxiliaram na construção de uma cronologia referente à história da indústria da música. Foi necessário consultar autores sobre distribuição, mídias físicas e digitais. Além disso, alguns conceitos importantes foram abordados, como: comportamento geracional ( $\mathrm{X}$ e $\mathrm{Y}$ ), envolvimento no consumo, eu estendido, influências de compra, marketing nostálgico e renda discricionária.

Para atingir os objetivos pretendidos realizou-se pesquisa bibliográfica e de campo. Aquela foi informada no tópico anterior e esta foi composta por dezesseis entrevistas em profundidade, sendo oito entrevistados da geração $X$ e oito da Y. Os dados foram tratados por meio de análise de conteúdo e um dos artifícios utilizados nesse diagnóstico foi a utilização de nuvens de palavras.

Dentre as principais questões abordadas salientam-se que o consumo de música é algo frequente na rotina de todos os entrevistados desse estudo. No grupo entrevistado, a geração $X$ revelou-se mais adepta de mídias físicas, enquanto a $\mathrm{Y}$, de digitais.

Apesar dessa distinção, verificou-se que a geração $X$ está cada vez mais interessada em tecnologia. Os mais novos entrevistados do Coorte $X$ já consomem músicas por meio de streaming e downloads pagos, como o iTunes. Portanto, estimular e ensinar o consumo de mídias digitais pode ser uma grande oportunidade para esse público que busca praticidade.

Com relação às mídias físicas, verifica-se que ainda há interesse, mesmo sendo menor na geração $\mathrm{Y}$. O que pode trazer oportunidades nesse segmento são embalagens/encartes com um bom apelo visual e preços condizentes com o 
que o público está disposto a pagar. Uma das grandes críticas são os preços abusivos e a baixa renda discricionária para aquisição de músicas em geral. Os shows podem continuar sendo comercializados em DVD para um público específico da geração $X$. Para a geração $Y$ seria mais indicado lançar os shows em plataformas de streaming, posto que este estudo evidenciou uma alta aceitação de DVDs por pessoas da geração $X$ e baixa na $Y$.

Também discutiu-se a perspectivas de remuneração de artistas e gravadoras. Os respondentes que pagam por música revelaram-se a favor de pagar direitos autorais, mas alguns expressaram uma imagem ruim das gravadoras, já que acreditam que elas remuneram mal. No grupo de entrevistados que não costumam pagar por música, houve uma tendência a acreditar que a internet serve como divulgadora e não distribuidora. Assim, consumir ilegalmente pode se reverter em ingressos de shows e assim remunerar o artista.

Sites, como o citado Brandcamp, podem se beneficiar da má impressão que algumas pessoas possuem das gravadoras para se promoverem, pois tal serviço serve como um canal direto, onde os artistas expõem seus trabalhos e 0 público remunera com o valor que acha justo pagar.

Por fim, enquanto os entrevistados da geração $X$ são mais influenciados por fatores sociais, principalmente amigos e família, a geração $Y$ possui uma influência pessoal, devido seu estilo de vida mais conectado. Além disso, o consumo de singles ou álbum inteiro mostrou-se algo independente de geração. Entre os participantes da pesquisa, os que consomem mídias físicas tendem a consumir álbuns inteiros e os digitais a ouvir músicas isoladas.

A figura 7 ilustra todas as palavras faladas pelos entrevistados de cada geração. 


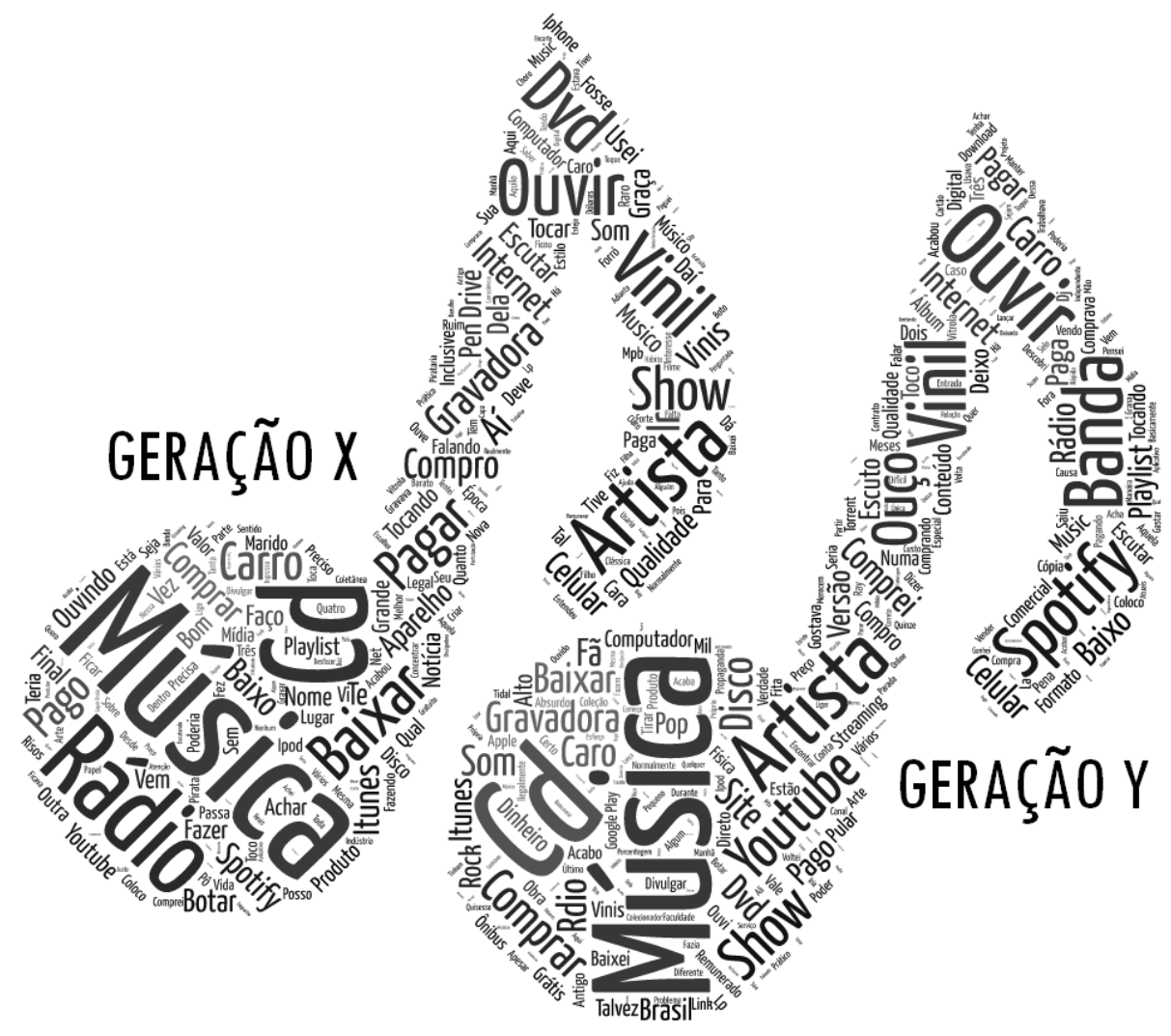

Fonte: Autoria própria com auxílio do site Tagul.com

Figura 7 - Nuvens de palavras de todas as entrevistas

\subsection{Sugestões e recomendações para novos estudos}

Como desdobramentos futuros, essa linha de estudo pode ser desenvolvida através de investigação quantitativa sobre o tema. Afinal, uma das limitações de um estudo exploratório qualitativo é justamente não ter o conceito de amostra representativa. Logo, um estudo quantitativo pode ser interessante.

Outras sugestões para futuros estudos:

- Consumo de vinil pela geração Y: o impacto do marketing nostálgico;

- A imagem da marca das grandes gravadoras: foi marcante nesse estudo a imagem ruim que as gravadoras possuem por consumidores de ambas as gerações;

- Renda discricionária para música: entender até que ponto uma pessoa pode diminuir ou deixar de consumir música devido a dificuldades financeiras, já que, a música se mostrou tão importante na vida das pessoas; 
- A internet como forma de divulgação e não distribuição: entender se a distribuição de música gratuita gera realmente um maior interesse por artistas a ponto de compensar a remuneração por meio de shows;

- Single vs álbum: investigar se o conceito de álbum, promovido desde os LPs, está realmente sendo substituído pelos singles;

- Serviço de streaming: entender qual a diferenciação entre as diferentes empresas prestadoras de tal serviço e verificar se o consumidor percebe tais diferenças. 


\section{Referências Bibliográficas}

ABPD (Associação Brasileira de Produtores de Discos). O Mercado De Música Brasileira 2014. Rio de Janeiro, 2015 Disponível em: <http://www.abpd.org.br/home/numeros-do-mercado/>. Acesso em: 06 de setembro. 2015.

APPLE. iTunes music store downloads top half a billion songs. Cupertino, CA, 2005. Disponível em: <http://www.apple.com/pr/library/2005/07/18iTunesMusic-Store-Downloads-Top-Half-a-Billion-Songs.html>. Acesso em: 06 de setembro de 2015.

BARDIN, L. Análise de conteúdo. Lisboa: Edições 70, 1977.

BORGES, Valterlei. Novos modelos de produção musical e consumo - Um estudo sobre as mudanças ocorridas com 0 advento das plataformas digitais. Niterói, 2011. Dissertação (Mestrado em Ciência da Arte) Departamento de Ciência da Arte: Universidade Federal Fluminense.

CHURCHILL, G.; PETER, J.P. Marketing - Criando Valor para os Clientes. 3.ed; São Paulo: Saraiva, 2013.

CROWL, Harry. A criação musical erudita e a evolução das mídias: dos antigos $78 \mathrm{rpm}$ à era do pós-CD. In: PERPETUO, Irineu Franco e SILVEIRA, Sergio Amadeu 164 (Orgs.). O futuro da música depois da morte do CD. São Paulo: Momento Editorial, p. 143-157, 2009.

DESPERTAI. Como a música afeta você. Despertai, São Paulo: Agosto, p.3, agosto. 2011.

ELGERSE, Anita; SMITH, Stacie. Beyoncé. Cambridge, 2014. p. 1 Caso Departamento de Administração: Harvard Business School.

EONLINE. Taylor Swift bate recorde com primeira semana de venda de 1989. Rio de Janeiro, 2014 Disponível em: <http://br.eonline.com/2014/taylorswift-bate-recorde-com-primeira-semana-de-venda-de-1989/>. Acesso em: 07 de setembro de 2015.

ÉPOCA. Taylor Swift x Spotify: como artistas lidam com a mudança da indústria audiofônica. Rio de Janeiro, 2014 Disponível em: <http://epoca.globo.com/ideias/noticia/2014/11/btaylor-swift-x-spotifyb-comoartistas-lidam-com-mudança-da-industria-audiofonica.html>. Acesso em: 07 de setembro. 2015.

ESTADÃO. Pirataria musical movimenta US\$ 4,5 bilhões. São Paulo, 2004 Disponível em: <http://www.estadao.com.br/noticias/geral,pirataria-musicalmovimenta-us-4-5-bilhoes,20040722p56903 >. Acesso em: 07 de outubro. 2015.

FLICK, U. Introdução à pesquisa qualitativa. São Paulo: Artmed, 2009. 
GAZETA ONLINE. Músicos criam estratégias para vender discos na era da web. Rio de Janeiro, 2014 Disponível em: <http://gazetaonline.globo.com/novo/_conteudo/2014/02/entretenimento/cultura e_famosos/1479752-musicos-criam-estrategias-para-vender-discos-na-era-daweb.html>. Acesso em: 07 de setembro. 2015.

GENES, Felipe; CRAVEIRO, Rodolfo; PROENÇA, Adriano. Inovações tecnológicas na cadeia produtiva da música no século XXI. Revista Sistema e Gestão, n.7, p. 173-190, 2012.

GIL, Antonio Carlos. Métodos e Técnicas de Pesquisa Social. 5.ed. São Paulo: Atlas, 2007.

GOMES, Rodrigo M. Do fonógrafo ao MP3: Algumas reflexões sobre música e tecnologia. Revista Brasileira de Estudos da Canção, n.5, p. 73-82, 2014.

GOMES, K. M. C.; AZEVEDO, L. R.; PEÇANHA, W. A. Design Retrô e Marketing do Saudosismo: Influência da Tendência Nostálgica no Comportamento do Consumo. Rio de Janeiro, 2014. Monografia para Especialização em Gestão, Design e Marketing - Departamento de Design: Instituto Federal Fluminense.

IFPI (International Federation Of The Phonographic Industry). IFPI Digital Music Report. Londres, 2010 Disponível em: <http://ifpi.org/digital-music-report.php>. Acesso em: 06 de setembro. 2015.

KIKKO, V. O. O futuro da indústria da música no Brasil. São Paulo, 2012. 25 p. Dissertação (Mestrado em Administração) - Departamento de Administração: Fundação Getúlio Vargas

KOTLER, P.; KELLER, K. Administração de Marketing. 12.ed.; São Paulo: Pearson, 2012.

KRETZER, Jucélio; TOYAMA, Miriam. Inovações Tecnológicas e Mecanismos de Proteção aos Direitos Autorais na Indústria Fonográfica. Revista Brasileira de Inovação, [S.I.], v. 7, n. 1 jan/jun, p. 177-207, aug. 2008. ISSN 2178-2822.

MARTINS, J. P. C. O mercado de música digital: um estudo sobre o comportamento do consumidor brasileiro perante o uso de música na internet. Porto Alegre, 2012. 15 p. Dissertação (Mestrado em Administração) Departamento de Administração: Universidade Federal do Rio Grande do Sul.

MILLES, S. O MP3 e o fim da ditadura do álbum comercial. In: PERPETUO, Irineu Franco e SILVEIRA, Sergio Amadeu 164 (Orgs.). O futuro da música depois da morte do CD. São Paulo: Momento Editorial, p. 75-90, 2009.

OLHAR DIGITAL. Streaming está matando a pirataria no Brasil. Rio de Janeiro, 2015 Disponível em: <http://www.olhardigital.uol.com.br/pro/noticia/straming-esta-matando-a-piratariano-brasil/46412/>. Acesso em: 07 de setembro. 2015.

PICCINO, Evaldo. Um breve histórico dos suportes sonoros analógicos. Revista Sonora. v.1, n. 2 p. 1-25, 2008. 
RIAA. Deep Dive: RIAA's Mid-Year Revenue Data. Washington, 2015 Disponível em: <https://www.riaa.com/blog.php?content_selector=deep-dive-riaamid-year-revenue-data\&blog_selector=deep-dive-riaa-mid-year-revenuedata\&news_month_filter=9\&news_year_filter $=2015 \&$ searchterms $=$ vinyl\&termincl ude $=\&$ termexact $=>$. Acesso em: 07 de outubro. 2015.

ROSENBLOOM, Bert. Canais de marketing: uma visão gerencial. 2.ed. São Paulo: Atlas, 2011.

SCHEWE, Charles D.; MEREDITH, Geoffrey; NOBLE, Stephanie M. Defining moments: segmenting by cohorts. Marketing Management, Chicago, v. 9, n. 3, p. 48-53, Fall 2000.

SCHEWE, Charles D.; MEREDITH, Geoffrey. (2004), Segmenting global markets by generational cohorts: determining motivations by age. Journal of Consumer Behaviour, 4: 51-63. doi: 10.1002/cb.157

SOLOMON, M. O comportamento do consumidor - comprando, possuindo, sendo. 10.ed. Porto Alegre: Bookman, 2011.

THE WALL STREET JOURNAL. For Taylor Swift, the future of music is a love story. Rio de Janeiro, 2015 Disponível em: <http://www.wsj.com/articles/fortaylor-swift-the-future-of-music-is-a-love-story-1404763219>. Acesso em: 07 de setembro. 2015.

VERGARA, Sylvia Constant. Métodos de Pesquisa em Administração. 6.ed. São Paulo, Atlas, 2012.

ZIKMUND, W. Princípios da Pesquisa de Marketing. 2.ed. São Paulo: Pioneira Thomson Learning, 2006. 


\section{Anexo 1: Roteiro das entrevistas}

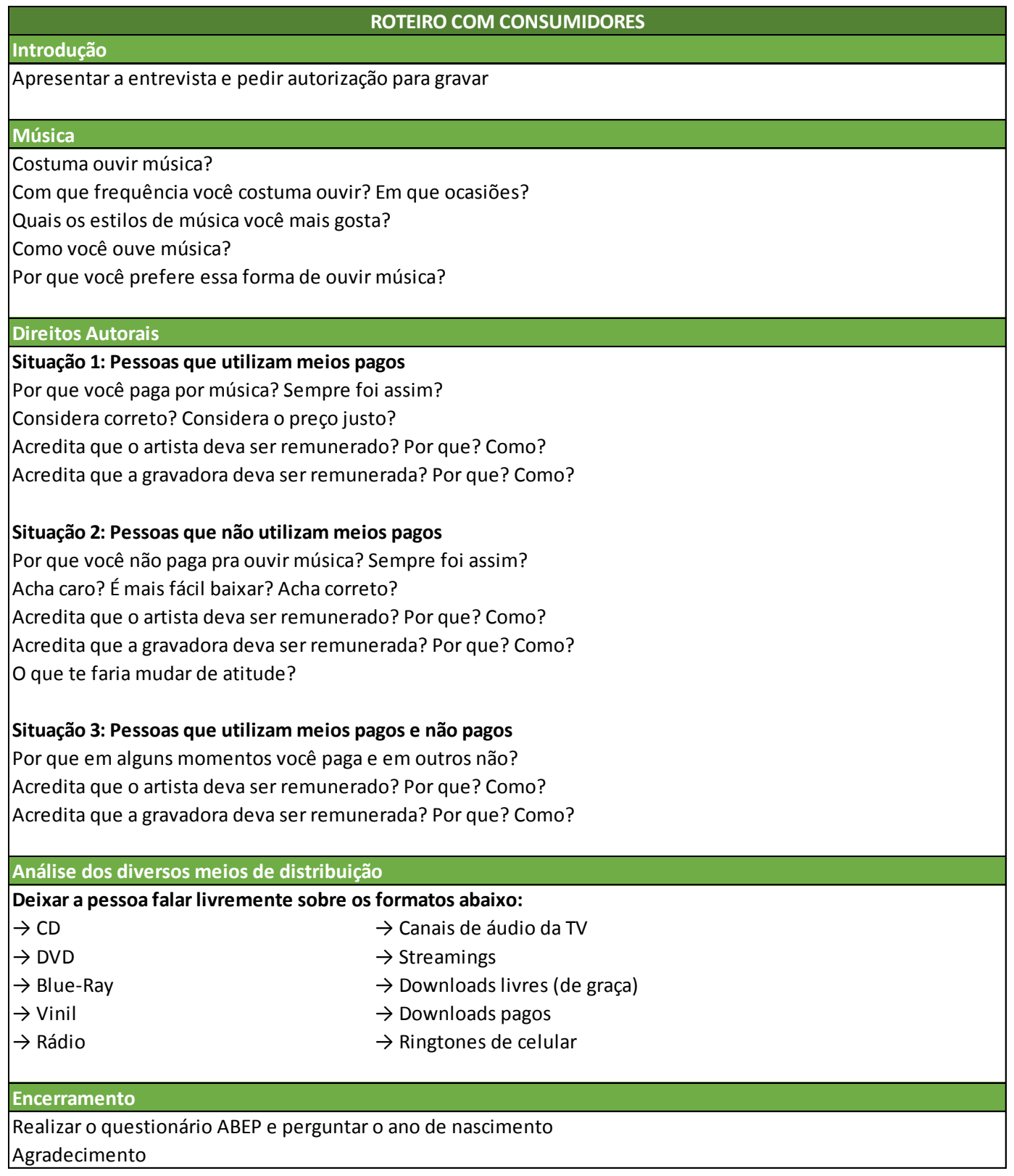


Anexo 2: Critério ABEP

\begin{tabular}{|c|c|c|c|c|c|}
\hline \multicolumn{6}{|c|}{ MODELO DE QUESTIONÁRIO SUGERIDO PELA ABEP } \\
\hline \multirow[b]{2}{*}{ Itens de Conforto } & \multicolumn{5}{|c|}{ QUANTIDADE } \\
\hline & 0 & 1 & 2 & 3 & $4+$ \\
\hline \multicolumn{6}{|l|}{$\begin{array}{l}\text { Quantidade de automóveis de passeio exclusivamente para uso } \\
\text { particular }\end{array}$} \\
\hline \multicolumn{6}{|l|}{$\begin{array}{l}\text { Quantidade de empregados mensalistas, considerando apenas } \\
\text { os que trabalham pelo menos cinco dias por semana }\end{array}$} \\
\hline \multicolumn{6}{|l|}{ Quantidade de máquinas de lavar roupa, excluindo tanquinho } \\
\hline \multicolumn{6}{|l|}{ Quantidade de banheiros } \\
\hline \multicolumn{6}{|l|}{$\begin{array}{l}\text { DVD, incluindo qualquer dispositivo que leia DVD e } \\
\text { desconsiderando DVD de automóvel }\end{array}$} \\
\hline \multicolumn{6}{|l|}{ Quantidade de geladeiras } \\
\hline \multicolumn{6}{|l|}{$\begin{array}{l}\text { Quantidade de freezers independentes ou parte da geladeira } \\
\text { duplex }\end{array}$} \\
\hline \multicolumn{6}{|l|}{$\begin{array}{l}\text { Quantidade de microcomputadores, considerando } \\
\text { computadores de mesa, laptops, notebooks e netbooks e } \\
\text { desconsiderando tablets, palms ou smartphones }\end{array}$} \\
\hline \multicolumn{6}{|l|}{ Quantidade de lavadora de louças } \\
\hline \multicolumn{6}{|l|}{ Quantidade de fornos de micro-ondas } \\
\hline \multicolumn{6}{|l|}{$\begin{array}{l}\text { Quantidade de motocicletas, desconsiderando as usadas } \\
\text { exclusivamente para uso profissional }\end{array}$} \\
\hline $\begin{array}{l}\text { Quantidade de máquinas secadoras de roupas, considerando } \\
\text { lava e seca }\end{array}$ & & & & & \\
\hline
\end{tabular}

\begin{tabular}{|l|c|}
\hline \multicolumn{2}{|c|}{ A água utilizada neste domicílio é proveniente de... } \\
\hline Rede geral de distribuição & 1 \\
\hline Poço ou nascente & 2 \\
\hline Outro meio & 3 \\
\hline
\end{tabular}

\begin{tabular}{|l|c|}
\hline \multicolumn{2}{|c|}{ Considerando o trecho da rua do seu domícilio, a rua é... } \\
\hline Asfaltada / Pavimentada & 1 \\
\hline Terra / Cascalho & 2 \\
\hline
\end{tabular}

\section{Grau de Instrução da pessoa..}

Analfabeto / Fundamental I Incompleto (Primário)

Fundamental I Completo (Primário) / Fundamental II Incompleto (Ginásio)

Fundamental II Completo (Ginásio) / Médio Incompleto (Colegial)

Médio Completo (Colegial) / Superior Incompleto

Superior Completo 


\begin{tabular}{|c|c|c|c|c|c|}
\hline \multicolumn{6}{|c|}{ SISTEMA DE PONTOS DO MODELO DE QUESTIONÁRIO SUGERIDO PELA ABEP } \\
\hline \multirow[b]{2}{*}{ Itens de Conforto } & \multicolumn{5}{|c|}{ QUANTIDADE } \\
\hline & 0 & 1 & 2 & 3 & $4+$ \\
\hline Banheiros & 0 & 3 & 7 & 10 & 14 \\
\hline Empregados domésticos & 0 & 3 & 7 & 10 & 13 \\
\hline Automóveis & 0 & 3 & 5 & 8 & 11 \\
\hline Microcomputador & 0 & 3 & 6 & 8 & 11 \\
\hline Lava Louça & 0 & 3 & 6 & 6 & 6 \\
\hline Geladeira & 0 & 2 & 3 & 5 & 5 \\
\hline Freezer & 0 & 2 & 4 & 6 & 6 \\
\hline Lava Roupa & 0 & 2 & 4 & 6 & 6 \\
\hline DVD & 0 & 1 & 3 & 4 & 6 \\
\hline Micro-ondas & 0 & 2 & 4 & 4 & 4 \\
\hline Motocicleta & 0 & 1 & 3 & 3 & 3 \\
\hline Secador de Roupa & 0 & 2 & 2 & 2 & 2 \\
\hline
\end{tabular}

\begin{tabular}{|c|c|c|c|}
\hline \multicolumn{4}{|c|}{ SERVIÇOS PÚBLICOS } \\
\hline & & Não & SIM \\
\hline Água encanada & & 0 & 2 \\
\hline Rua pavimentada & & 0 & 4 \\
\hline
\end{tabular}

ESCOLARIDADE

Analfabeto / Fundamental I Incompleto (Primário) Fundamental I Completo (Primário) / Fundamental II Incompleto (Ginásio)

Fundamental II Completo (Ginásio) / Médio Incompleto (Colegial)

Médio Completo (Colegial) / Superior Incompleto

Superior Completo

\begin{tabular}{|c|c|c|}
\hline \multicolumn{3}{|c|}{ CORTES DO CRITÉRIO BRASIL } \\
\hline Classe & Pontos & Renda Média Domiciliar \\
\hline A & $45-100$ & $20.272,56$ \\
\hline B1 & $38-44$ & $8.695,88$ \\
\hline B2 & $29-37$ & $4.427,36$ \\
\hline C1 & $23-28$ & $2.409,01$ \\
\hline C2 & $17-22$ & $1.446,24$ \\
\hline D - E & $0-16$ & 639,78 \\
\hline
\end{tabular}

Fonte: Adaptado do material Critério ABEP 2015 